\title{
A Simple Macro-Fiscal Model for Policy Analysis: An Application to Cambodia
}

\section{Daniel Baksa ${ }^{1}$ \\ Ales Bulir ${ }^{2}$ \\ Dyna Heng ${ }^{\rtimes}$}

20,s International Monetary Fund, USA.

'Email:dbaksa2@imf.org Tel: +1202-437-9106

${ }^{2}$ Email: abulir@imf.org Tel: +1202-683-0115

${ }^{s}$ Email: dheng@imf.org Tel: +1202-304-9167

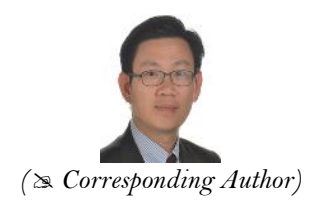

\begin{abstract}
Macroeconomic management in many developing countries is often heavily dependent on fiscal policies. This paper develops a semi-structural macro-fiscal model for simulating and forecasting macroeconomic policies in Cambodia. The model is calibrated to capture key characteristics of Cambodia's economy and serves as a tool for scenario analysis. We demonstrate its application with an illustrative scenario of the macroeconomic effects of the Covid-19 pandemic. The model's results conform with past empirical analyses of the Cambodian economy and generate intuitive and easyto-understand policy scenarios. Complemented with near-term forecasting tools and expert judgment, the dynamics of the model help to inform policymakers about medium-term transmission channels and thus guide policy advice. In particular, the results could serve as an input for the country's medium-term fiscal framework and debt sustainability analysis.
\end{abstract}

Keywords: Business cycle, Fiscal policy, Cambodia, Forecasting, Simulation, Debt management.

JEL Classification: E32; E52; E58; E62; F47, H68.

Citation | Daniel Baksa; Ales Bulir; Dyna Heng (2022). A Simple Macro-Fiscal Model for Policy Analysis: An Application to Cambodia. Asian Journal of Economics and Empirical Research, 9(1): 21-37.

History:

Received: 14 December 2021

Revised: 16 February 2022

Accepted: 25 February 2022

Published: 28 February 2009

Licensed: This work is licensed under a Creative Commons Attribution 3.0 License $(\mathrm{cc})$ E)

Publisher: Asian Online Journal Publishing Group
Funding: This study received no specific financial support.

Authors' Contributions: All authors contributed equally to the conception and design of the study.

Acknowledgement: This paper was originally published as an IMF Working Paper. It greatly benefited from discussions with the staff of Cambodia's Ministry of Economy and Finance and the National Bank of Cambodia. The views expressed in this paper are those of the authors and not necessarily those of the Cambodian authorities, the International Monetary Fund, or its Executive Board.

Competing Interests: The authors declare that they have no conflict of interest.

Transparency: The authors confirm that the manuscript is an honest, accurate, and transparent account of the study; that no vital features of the study have been omitted; and that any discrepancies from the study as planned have been explained.

Ethical: This study followed all ethical practices during writing

\section{Contents}

\section{Introduction}

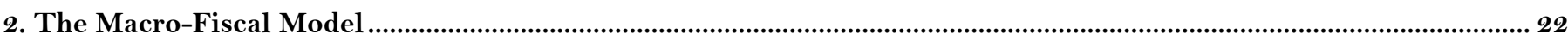



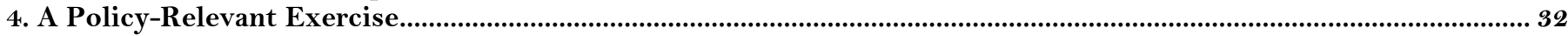

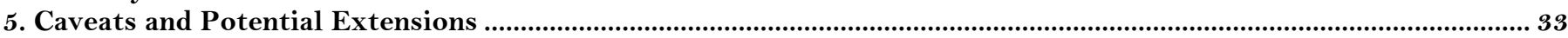

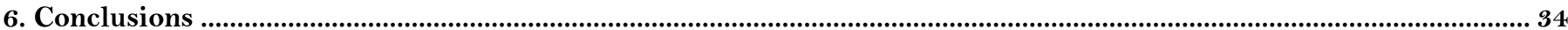

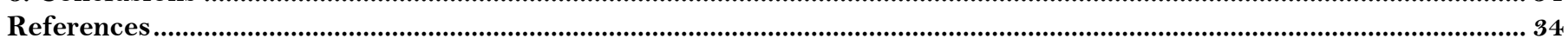




\section{Contribution of this paper to the literature}

This paper contributes to the growing literature on forecasting and policy analysis systems that in many countries are designed to support forward-looking fiscal and monetary policy formulation. This paper presents a macro-fiscal tool, the simulation results of which can serve as inputs for a medium-term fiscal framework in Cambodia.

\section{Introduction}

For the past 30 years, economists have been building simple, policy-relevant models, typically with either a monetary or a fiscal transmission mechanism. Rarely do these models give equal attention to both. Most policy applications have been adopted by central banks rather than ministries of finance. In contrast, we build a parsimonious semi-structural model that can be used to simulate and forecast the effects of both monetary and fiscal policies for all relevant monetary and exchange rate arrangements. Compared to more detailed frameworks, including those of the IMF financial programming (FP), which are built around many variables and identities, this model uses fewer variables and binds them together in a way that has been tested both theoretically and empirically. We have adapted the basic approach for use in Cambodia and present a scenario of possible macroeconomic effects of the Covid19 pandemic there.

We augment the standard New Keynesian monetary transmission channels for stylized fiscal interactions and debt dynamics; for the former, our model consists of an aggregate demand (IS) curve, a price-setting (Phillips) curve, an uncovered interest rate parity (UIP) relationship, and a monetary policy reaction function that reflects the given monetary and exchange rate arrangement. ${ }^{1}$ These building blocks capture the principle that the fundamental role of monetary policy is to anchor inflation and inflation expectations. To capture the role of the fiscal authority, we add the fiscal balance, its financing, debt dynamics, and a fiscal policy reaction function. This structure is consistent with a view of the world in which because nominal and real rigidities prevent the instantaneous adjustment of prices and wages, in the short run, aggregate demand determines output; also, expectations play a role in inflation, output, and fiscal sustainability, and both monetary and fiscal policy are rule-based and predictable.

The presented model simplifies the task of analyzing scenarios for macroeconomic policies and assessing their impact. Developing and comparing such scenarios is time-consuming, particularly when ensuring internal consistency despite a lack of solid structure. A parsimonious model that can be scaled up could become the mainstay of a standard analysis toolkit. The goal of this paper is to first define and then test such a minimalist approach. To be applicable, a policy-oriented macroeconomic model must satisfy two conditions: (1) it must take into account generally accepted fiscal and monetary transmission channels, and (2) it should be parsimonious so that it is usable in countries with low-frequency data and without a tradition of model-based policy analysis. Indeed, our target audience is a country that does not have sophisticated models to support macroeconomic decision-making at its disposal.

Cambodia is a fast-growing, lower-middle-income, open economy. Because it is vulnerable to adverse external shocks, its policymakers seek to understand how such shocks are propagated, their medium- and long-term impacts on Cambodia's economy, and the likely effects of different domestic policy responses to these shocks. To serve as a tool for scenario analysis, we develop and calibrate a simple, macro-fiscal, semi-structural model that captures stylized facts about Cambodia's economy. We call it the Cambodia Macro-Fiscal Model (CAMFI). The key benefit of our approach is that it strictly limits the number of macroeconomically relevant variables while maintaining theoretical consistency. For the sake of parsimony, we drop sectors and variables that are less relevant to the specific analysis or that cannot be easily modeled for Cambodia. For example, in Cambodia, policy analysis focuses on domestic developments, but because the current account deficit is financed entirely by sustainable foreign direct investment (FDI) inflows, there is little benefit in modeling components of the trade or financial balance. Similarly, because the supply side of the semi-structural models is largely exogenous, there is little to gain from modeling revenue and expenditure components-imposing revenue- and expenditure-specific multipliers would be superficial. Therefore, in our model, the fiscal authority chooses a single policy variable: the cyclically-adjusted primary balance.

We recognize that by simplifying the external sector into a risk premium variable or aggregating all fiscal operations into the primary balance variable we are foregoing the possibility of a more granular analysis. Should the simulation tasks change or different sectors and components gain prominence, the model would need to be either extended to account for such new factors or supplemented by satellite models. We remain mindful, however, of the cost of expansion - the comparative simplicity of this model allows much simpler data updates than traditional frameworks with many variables.

We calibrate the model, apply it to the Cambodian data, and then illustrate how it works in several applications: impulse response functions, a multivariate filtration to obtain important unobserved variables, a test of the model's recursive forecasting capability, and the design of an exercise to simulate the medium-term economic impact of Covid19 shock. The CAMFI results conform with past empirical analyses of the Cambodian economy and stylized facts, as well as generating intuitive and easy-to-understand policy scenarios.

The rest of the paper is organized as follows: Section II describes the semi-structural model, with a fiscal extension. Section III briefly discusses recent developments in Cambodia and their implications for the calibration of the model. Section IV illustrates applications of the CAMFI model in assessing the economic impact of Covid-19 in Cambodia. Section V discusses caveats and the potential extension of the model. Section VI concludes.

\section{The Macro-Fiscal Model}

The semi-structural model we present here is similar to those many central banks use for policy analysis; it generally corresponds to what Fukac and Pagan (2010) called the 3rd Generation (3G) of policy models. A steadystate model is at the core of $3 \mathrm{G}$ frameworks: the dynamics embedded in the model describe the transition from one steady state to another, so that solving the model produces a transitional steady-state solution for its variablesthey will vary over time because movements from one point to another are not instantaneous. In addition, because 
some variables are taken to be exogenous and are thus treated as determined outside the model economy, they need not correspond to their steady-state values in any period. As attention is centered on the "gap" between the steadystate estimate, $z_{t}^{*}$, and the observed value, $z_{t}$, it is therefore natural to convert all the variables in the model to the gap format, producing what are often called "gap models" or "trend-gap models."

We have extended the model to incorporate a rudimentary fiscal and debt-accounting block, recast it to annual frequency, and calibrated it to capture the stylized facts of Cambodia's macroeconomic policies. It blends the New Keynesian emphasis on nominal and real rigidities and the role of aggregate demand in output determination with the real business cycle methods of dynamic stochastic general equilibrium (DSGE) modeling with rational expectations (Berg, Karam, \& Laxton, 2006). Rather than deriving the baseline model from strictly microeconomic foundations, we pragmatically allow both adaptive and rational expectations and substantial inertia in the equations to match the data.

The CAMFI model has five building blocks, as summarized in Figure 1 and detailed in Appendix C:

1. An aggregate demand or IS curve that relates the level of real activity to expected and past real activity, the real interest rate, the real exchange rate, the fiscal impulse, and foreign demand.

2. A price-setting or Phillips curve that relates current inflation to past and expected inflation, the output gap, the exchange rate, and oil prices. The relationships in (1) and (2) are independent of the monetary and exchange rate regime prevailing in the country under consideration.

3. A UIP condition for the exchange rate that incorporates the country risk premium. This equation can take multiple forms in the model as it is formulated to reflect the exchange rate regime-in the case of Cambodia, a heavily-managed float that has stabilized the exchange rate at about 4,050 riels per US $\$ 1$, with an open capital account. ${ }^{2}$ Here, for the sake of parsimony, we have chosen to omit the external balances. The sizable current account deficit has been (over)financed by sustainable FDI inflows (IMF (International Monetary Fund), 2019). The UIP is also the model's reaction function for setting the domestic interest rate: the foreign rate plus a country risk premium (Obstfeld, Shambaugh, \& Taylor, 2005). Thus, monetary policy passively accommodates movements in the world interest rate. The National Bank of Cambodia (NBC) has been keeping the exchange rate stable through a strict policy of not lending to the government - thus also signaling its independence. The monetary and exchange rate regime in our model is tailored to Cambodia's stylized facts, and the equations are regime-dependent: for a country with an independent monetary policy a different specification would be required.

4. The model is expanded to incorporate a fiscal policy reaction function. In practice, the Cambodian government has been following the "fiscal golden rule" for its current fiscal balance, while borrowing externally for some investment spending. ${ }^{3}$ This policy is equivalent to saying that the fiscal authority decides on a cyclicallyadjusted primary deficit, taking into account the country's cyclical position and its announced gross debt target.

5. The model is closed with the usual debt accounting identity. The deficit is financed either by accumulating debt or dissaving government deposits. Above-target debt increases the risk premium and thus raises the neutral real interest rate and vice versa.

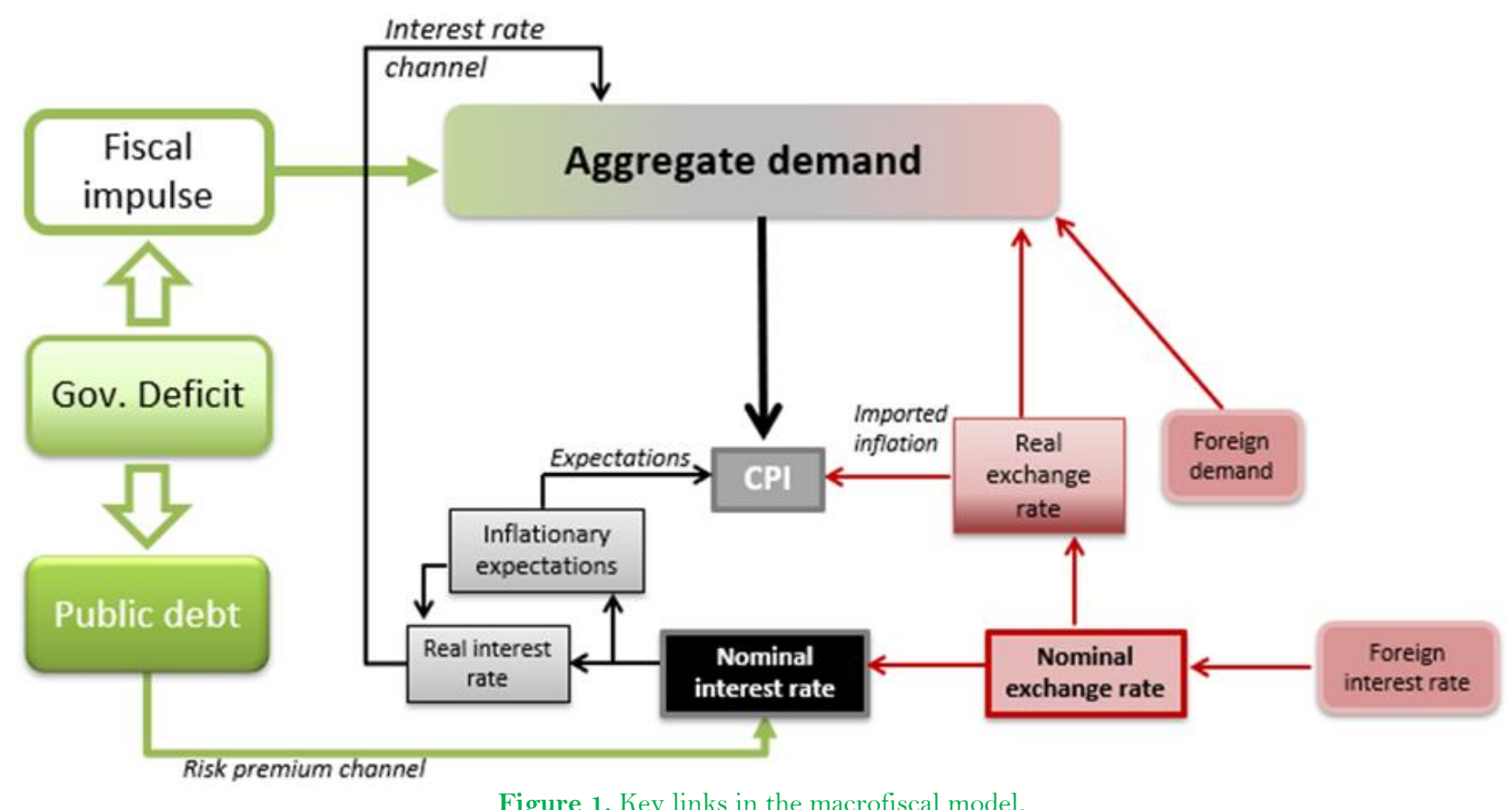

\section{A. Aggregate Demand}

The aggregate demand relationship - the IS curve-links the domestic output gap to past and expected output gaps, monetary conditions, the fiscal stance, and the foreign output gap:

$$
\hat{y}_{t}=a_{1} \hat{y}_{t-1}+a_{2} E_{t} \hat{y}_{t+1}-a_{3} m c i_{t}+a_{4} f_{t}^{i m p}+a_{5} \hat{y}_{t}^{*}+\varepsilon_{t}^{y},
$$

where $\hat{y}_{t}$ is the output gap, defined as the deviation of the log of real output from its trend, $m c i_{t}$ denotes the real monetary conditions index, $f_{t}^{i m p}$ is the fiscal impulse, $\hat{y}_{t}^{*}$ is the foreign output gap, and $\varepsilon_{t}^{y}$ is an aggregate demand shock.

\footnotetext{
2 "The de jure exchange rate arrangement is a managed float. Given the high degree of financial dollarization, the National Bank of Cambodia (NBC) intervenes in the foreign exchange market to accommodate demand for riels and maintain exchange rate stability. The de facto exchange rate arrangement is classified as

${ }^{3}$ ther managed." (IMF (International Monetary Fund), 2018c).
${ }^{3}$ The current balance is the difference between current revenue and current expenditure and the "fiscal golden rule" states that over the economic cycle the government should borrow only to invest, not to fund current spending (see, e.g., HM Treasury (2008)).
} 
All parameters- $a_{i}, b_{i}, e_{i}, f_{i}$, and $g_{i}$-have positive values, and $E_{t}$ denotes model-consistent ("rational") forwardlooking expectations. The gaps, denoted with "hats," are calculated as differences of the actual, observed variables from their estimated trends, denoted with tildes,

$$
\hat{x}_{t}=x_{t}-\tilde{x}_{t} \text {. }
$$

The real monetary conditions index $(m c i)$ is defined as a weighted average of deviations of the real interest rate, the credit risk premium, and the real exchange rate from their trends:

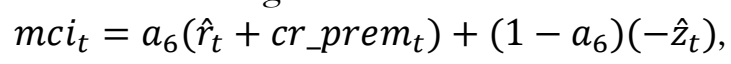

where $\hat{r}_{t}$ is the deviation of the real interest rate $\left(\hat{r}_{t}=i_{t}-E_{t} \pi_{t+1}-\tilde{r}_{t}\right)$ from its trend (neutral, $\left.\tilde{r}_{t}\right)$ level, cr_prem $_{t}$ is the credit risk premium, and $\hat{z}_{t}$ is the deviation of the real exchange rate from its trend.

What kind of interest rate do we have in mind? As long as the term and risk premiums for various maturities and financial instruments evolve in tandem, we can work with the short-term, interbank interest rate so that innovations are transmitted along the yield curve." The real interest rate, $r_{t}$, applies only to private debt service; it reflects, among other factors, the country risk premium and external financial developments. Another real interest rate, $r_{t}^{g o v}$, in the model applies only to concessional borrowing by the government; it is low and stable. As is discussed below, because Cambodia's public debt is all on concessional terms, it is reasonable to disconnect these two interest rates, especially since the interest rate on public debt was stable even through the global financial crisis (GFC).

The real exchange rate is defined as the nominal exchange rate adjusted for differences in domestic and world price levels, $z_{t}=s_{t}+p_{t}^{*}-p_{t}$, where $s_{t}$ are units of domestic currency (for Cambodia, the riel) per US dollar, $p_{t}^{*}$ is the foreign and $p_{t}$ the domestic CPI index. Thus, an increase in $z_{t}$ implies a more depreciated — and a decrease a more appreciated-domestic currency in real terms.

The fiscal impulse, $f_{t}^{i m p}$, defined as the change in the cyclically-adjusted balance, $\operatorname{cad}_{t}$, indicates whether current fiscal policy is adding to or subtracting from aggregate demand (see more on the cad variable in Section 2.D). The fiscal impulse also reflects movements in the debt target or the discretionary changes in the debt ratio:

$$
f_{t}^{i m p}=\left(\operatorname{cad}_{t}-\operatorname{cad}_{t-1}\right)+f_{4} \varepsilon_{t}^{b^{\text {tar }}} \pm f_{5} \varepsilon_{t}^{b},
$$

where $\varepsilon_{t}^{b^{t a r}}$ is a shock to the debt target and $\varepsilon_{t}^{b}$ a shock to the debt ratio. The former makes it possible to capture the expansionary effect of an announcement of a higher or lower debt target - the agents will expect a sequence of corresponding positive or negative future fiscal impulses and adjust their expected spending accordingly. The latter makes it possible to model the impact of debt changes as either traditional Keynesian contractionary stabilizations $\left(f_{5}>0\right)$ or non-Keynesian expansionary stabilizations $\left(f_{5}<0\right)$, as defined by Alesina and Ardagna (2010). While the model does not detail the transmission mechanism, based on expert judgment it is possible to design fiscal stabilization scenarios as contractionary, expansionary, or growth-neutral $\left(f_{5}=0\right) .{ }^{5}$

Monetary policy affects aggregate demand through the real exchange rate and the real interest rate gaps, as aggregated in the monetary conditions index, $m c i_{t}$. Tighter monetary policy (a higher $m c i_{t}$ ) reduces the output gap either through a higher real interest rate $\left(\right.$ a higher $\hat{r}_{t}$ ) or an appreciated real exchange rate (a lower $\left.\hat{z}_{t}\right)$. Fiscal policy directly affects aggregate demand through the fiscal impulse - the parameter $a_{4}$ is very close to the impact multiplier (see Appendix B for a discussion of the value of the multiplier).

\section{B. Aggregate Supply}

The aggregate supply block, the Phillips curve, links inflation to adaptive and forward-looking expectations of inflation, real marginal costs, and oil prices:

$$
\begin{aligned}
& \pi_{t}=b_{1} \pi_{t-1}+\left(1-b_{1}\right) E_{t} \pi_{t+1}+b_{2} r m c_{t}+b_{3} \Delta o i l_{t}+\varepsilon_{t}^{\pi}, \\
& r m c_{t}=b_{4} \hat{y}_{t}+\left(1-b_{4}\right) \hat{z}_{t} .
\end{aligned}
$$

Current period inflation, $\pi_{t}$, depends on forward-looking inflation expectations $\left(E_{t} \pi_{t+1}\right)$, backward-looking expectations $\left(\pi_{t-1}\right)$, the real marginal costs $\left(r m c_{t}\right)$, and a change in dollar-denominated oil prices adjusted for exchange rate appreciation or depreciation, $\Delta o i l_{t}$. The term $r m c$ captures the weighted average of the real exchange rate gap and the output gap; in general, one can relate the real marginal cost for domestic producers to the output gap, $\hat{y}_{t}$, and that for importers to the real exchange rate gap, $\hat{z}_{t}$. The calibrated value of $b_{1}$ is our best guess of the share of backward-looking agents in the price-setting process. The product $b_{2} \cdot b_{4}$ measures the slope of the Phillips curve with respect to the output gap.

As is common in models that are designed to capture business cycle fluctuations, aggregate supply is largely an exogenous process. The economy grows along a calibrated potential output path that can be altered only marginally by movements in the equilibrium real interest rate. Specifically, in our model, higher-than-targeted public debt raises both the country risk premium and the equilibrium interest rate, thus depressing the rate of growth of potential output. We discuss the debt-to-potential-growth nexus in Section 2.D.

\section{The Exchange Rate, Uncovered Interest Rate Parity, and the Policy Reaction Function}

Exchange rate regimes require appropriate equations to capture their role. Moreover, the specifications must be consistent with the monetary policy regime. ${ }^{6}$ Fortunately, there are tested versions of these equations for all regime combinations. Cambodia's combination is straightforward: a heavily managed exchange rate with an open capital account. From mid-2008, the riel-to-dollar rate has oscillated around a mean of about 4,050 riels, we thus treat this

\footnotetext{
${ }^{*}$ See Bulír and Vlček (2021). Assumption of a stable factor greatly simplifies the model, making it unnecessary to build an explicit term structure of interest rates-most private-sector lending in Cambodia has a maturity of at most one year. In fact, the terms for private sector loans of various maturities have been relatively stable.

${ }^{5}$ In a traditional Keynesian fiscal stabilization, either through higher taxes or lower spending, lower debt $\left(\varepsilon_{t}^{b}<0\right)$ will cause a negative fiscal impulse, hence, $f_{5}>0$. Under which circumstances could stabilization be expansionary $\left(f_{5}<0\right)$ ? Some economists have argued that a fiscal adjustment today removes expectation of future harsher adjustments or future tax hikes, thus stabilizing expectations, increasing consumer expected disposable income, boosting the confidence of investors, and therefore stimulating private demand (Giavazzi \& Pagano, 1996).

${ }^{6}$ The Mundell-Fleming trilemma says that each country must choose between the objectives of free capital mobility, exchange-rate management, and monetary autonomy (Obstfeld et al., 2005)—only two can be pursued simultaneously.
} 
value as an implicit but widely understood and credible exchange rate target. We assume that the NBC's international reserves are sufficient to keep the exchange rate stable. Thus, in the model, we treat the exchange rate regime as a de facto peg.

It is useful to recall what a credible exchange rate commitment implies for competitiveness: the country cannot restore price competitiveness by devaluing the nominal exchange rate. Should the real exchange rate become misaligned-due to either a negative productivity shock or higher domestic inflation relative to its trading partners - the eventual realignment must come through lower-than-trading-partner wage and price inflation, i.e., internal devaluation. The peg is then effectively equivalent to a price-level targeting regime that ensures that purchasing power parity (PPP) holds in the medium term; thus, time subscripts are not necessary in our notation:

$$
\Delta \tilde{z}=\Delta \tilde{s}+\tilde{\pi}^{*}-\tilde{\pi}
$$

where $\tilde{z}$ denotes the trend rate of growth of the real exchange rate, i.e., "equilibrium" appreciation or depreciation, $\tilde{s}$ is the trend rate of growth of the nominal exchange rate, and $\tilde{\pi}^{*}$ and $\tilde{\pi}$ indicate foreign and domestic inflation trends. As long as the nominal exchange rate is pegged $(\Delta \tilde{s}=0)$ and the country desires to keep price competitiveness at the current level (hence, $\Delta \tilde{z}=0$ ), foreign and domestic price levels have to grow at the same pace over the medium term, $\tilde{\pi}^{*}=\tilde{\pi}$. This result is equivalent, of course, to price-level targeting. policy:

The UIP condition then pins down the domestic interest rate, $i_{t}$, since the NBC cannot pursue active monetary

$$
i_{t}=\left(E_{t} s_{t+1}-s_{t}\right)+i_{t}^{*}+\text { prem }_{t}+\varepsilon_{t}^{s}
$$

where $s_{t}$ is the nominal exchange rate defined in domestic currency terms per US dollar, $E_{t} s_{t+1}$ is the modelconsistent expectation of the nominal exchange rate in period $t+1$ (as long as the peg remains credible, $\Delta E_{t} s_{t+1}=$ $0), i_{t}^{*}$ is the foreign nominal interest rate, prem $_{t}$ is the country risk premium, which is expected to increase or decrease with government debt compared to the target level, and $\varepsilon_{t}^{S}$ is the exchange rate shock.

\section{The Fiscal Block}

The model is closed with an aggregated fiscal block that anchors the public's expectations of fiscal sustainability and links the fiscal policy (flow) variable with financing (stock) variables. Here, the fiscal authority decides on a sole policy variable, namely the cyclically-adjusted primary balance, guided by the country's cyclical position and its announced gross debt target. We justify the aggregation by noting that our semi-structural framework has an exogenously set supply side: the rate of potential growth does not depend on the mix of direct and indirect taxes, but is calibrated and assumed to remain constant for the duration of the simulations so that breaking down revenues or expenditures would be superficial with no feedback into the supply side. True, by aggregating all fiscal operations into a single variable we are foregoing the possibility of a granular analysis of multipliers and composition effects of fiscal policy, but in our view, decomposition is better left to a fully micro-founded DSGE model.

Fiscal authority decisions related to the golden rule can be simplified into two steps. (1) The policymaker decides on the cyclically-adjusted primary fiscal deficit, $\mathrm{cad}_{t}$. Because Cambodia's public borrowing has all been concessional, the government interest bill is not only small but is generally not sensitive to international rate movements and swings in risk premiums. ${ }^{7}$ (2) The policymaker decides how to finance the corresponding balance: either through debt accumulation or repayment, $\Delta b_{t}$, or through dissaving or accumulation of government deposits, $\Delta x_{t}$.

In line with the literature on fiscal rules, our fiscal policy reaction function has two competing objectives: to smooth output fluctuations and to anchor gross public debt to a target, which is presently calibrated at 30 percent of GDP (Plödt \& Reicher, 2015). Regarding the former, the fiscal authority wants to avoid large swings in the balance compared to the last period, $\operatorname{cad}_{t-1}$, and also wishes to respond to a positive or negative output gap, $\hat{y}_{t}$, with a tighter or looser deficit. Regarding the latter, debt stabilization implies setting the cyclically-adjusted balance at a level consistent with the debt target, $c a d_{t}^{\text {tar }}$, adjusted for the current-period deviation of debt from its target level, $b_{t}^{\text {dev }} .8$ Intuitively, lower-than-targeted debt $\left(b_{t}^{\text {dev }}<0\right)$ implies tighter fiscal policy, producing either a surplus or a smaller deficit than $\left(b_{t}^{d e v}=0\right)$, and vice versa:

$$
\operatorname{cad}_{t}=f_{7}\left(\operatorname{cad}_{t-1}-f_{10} \hat{y}_{t}\right)+\left(1-f_{7}\right)\left(\operatorname{cad}_{t}^{\mathrm{tar}}-f_{8} b_{t}^{\text {dev }}\right)+\varepsilon_{t}^{c d}
$$

The obvious implication of these two competing objectives is that in the short run neither is fully achievable: while the fiscal authority may want to stimulate the economy by running a larger cyclically-adjusted deficit, it would be held back by debt concerns. Similarly, a faster return to the debt target would conflict with the output-smoothing objective. Deviation from the debt target, $b_{t}^{\text {dev }}$, is a forward-looking process as the fiscal authority assesses both the current deviation and the expected future path, where the debt target itself could be time-varying:

$b_{t}^{d e v}=f_{9}\left(b_{t}-b_{t}^{\text {tar }}\right)+(1$
Debt accumulation follows the usual law of motion:

$$
b_{t}^{\text {dev }}=f_{9}\left(b_{t}-b_{t}^{\text {tar }}\right)+\left(1-f_{9}\right) E_{t} b_{t+1}^{\text {dev }} \text {. }
$$

$$
b_{t}=d_{t}+\Delta x_{t}+\left(1+\Delta s_{t}\right) b_{t-1} /\left(1+g_{t}\right)
$$

where $b_{t}$ is the debt-to-GDP ratio at year $t$, and $d_{t}$ is the overall deficit $\left(d_{t}>0\right.$ indicates a deficit, $d_{t}<0$ a surplus); $g_{t}$ is the growth rate of nominal GDP, $\Delta s_{t}$ denotes the revaluation term of foreign-currency-denominated concessional debt, and $\Delta x_{t}$ denotes changes in government deposits.

The choice of financing between changes in the stock of debt and the stock of deposits at the central bank goes beyond a simple accounting exercise-certainly in Cambodia. Disbursements by external lenders are relatively infrequent and mostly related to donor-funded investment projects. In the absence of short-term treasury bills or borrowing from the banking system, to finance its day-to-day operations the treasury has built a buffer of government deposits at the NBC. ${ }^{9}$ This brings up a somewhat peculiar feature of Cambodia's fiscal operations: in the short run,

${ }^{7}$ Recall that the market interest rate for the private sector differs from the interest rate on public debt.

${ }_{8}$ The cyclically-adjusted budget balance is the balance that would obtain when GDP reaches its potential. The cyclically-adjusted measure better describes the stance of fiscal policy than the headline balance, as it removes the endogenous components of spending and revenues. In our model we use the common definition of the cyclically-adjusted balance, see Fedelino, Ivanova, and Horton (2009): cad $=-\epsilon \hat{y}$, and our calibration of $\epsilon$ follows (Price, Dang, \& Botev, 2015).

9 The impact of changes in government deposits (negative net claims on government) on private sector lending depends on where government savings are deposited. If they are deposited in the central bank, as in Cambodia, the impact on private sector lending is zero. If they are deposited in commercial banks, their 
gross debt is "passive," reflecting the donor-driven supply of loans. In contrast, government deposits are an "active," domestically-determined variable. In good times, the fiscal authority borrows more than is needed and saves the proceeds in the central bank, effectively pre-financing future debt needs. In bad times, it draws down these deposits without needing to approach either concessional lenders or capital markets. The fiscal authority, therefore, targets a level of deposits that guarantees current and future payment of its bills, keeping in mind the cyclical position of the economy. We specify the following law of motion for government deposits, $\Delta x_{t}$ :

$$
\Delta x_{t}=g_{2} \Delta x_{t-1}+\left(1-g_{2}\right)\left(\Delta x_{t}^{\text {tar }}+g_{3} \hat{y}_{t}+g_{4}\left(p d_{t}-p d_{t}^{t a r}\right)\right)+\varepsilon_{t}^{x}
$$

where $x_{t}^{t a r}$ is the desired level of government deposits; based on the historic average, we calibrate its steadystate value at 8 percent of GDP. The policymaker will smooth out deposits around the target, accumulating deposits when the economy operates above its potential and "decumulating" when it operates below, and then accumulate or decumulate as needed, whenever the primary deficit deviates from the debt-stabilizing level.

A further reason to separate the financing items is their differential impact on the risk premium and thus on the neutral real interest rate. Empirically, countries with larger gross debt-to-GDP ratios have had to offer higher yields to investors (Engen \& Hubbard, 2004; Jaramillo \& Weber, 2012). During periods of financial turmoil, as in a cyclical downswing or with a primary deficit temporarily above the debt-stabilizing level, countries should be better off drawing down buffer stocks of deposits rather than borrowing at higher, non-concessional rates. ${ }^{10} \mathrm{~A}$ depositdissaving scenario would limit the impact on the risk premium and thus keep the equilibrium real interest rate lower than in the scenario with higher gross debt. Ultimately, higher equilibrium real interest rates limit growth because fewer investment projects are deemed profitable (Schumacher \& Żochowski, 2017).

\section{Recent Economic Developments in Cambodia and CAMFI Calibration}

With monetary policy limited by dollarization, the authorities have relied on fiscal policy to stabilize the economy. After sketching out the main stylized facts, we explore the implications for the calibration of our model. We must stress that all data, charts, and CAMFI simulation results are based on the mid-2020 vintage of the Cambodia dataset. Several of the series have subsequently been revised (e.g., fiscal deposits) or are due to be updated (e.g., nominal GDP is due for a substantial revision in 2022).

\section{A. Recent Economic Developments}

Since Cambodia's internal conflict ended in 1998, followed by the liberalization of trade and the capital account, the country has averaged real GDP growth of $7 \frac{3}{4}$ percent, with average inflation of about 4 percent. Growth has been driven by garment exports, tourism, and construction, much of it funded by foreign investment (Chart 1 in Figure 2). Openness to trade and capital flows under a stable exchange rate, while boosting growth, has also increased the country's external vulnerability, especially given its narrow economic base and increasing dependence on foreign funding. Cambodia does not borrow on private capital markets.

The economy is almost completely dollarized, which limits the NBC's monetary policy options (Charts 2 and 3). In 2019, more than 90 percent of savings, loans, and economic transactions were in US dollars, with the exchange rate averaging about 4,050 riels per dollar. Robust FDI inflows have contributed to gross international reserves equivalent to about 7 months of imports. Reserves have been assessed as adequate when measured against traditional metrics, but the IMF (International Monetary Fund) (2019) has encouraged further accumulation.

Given the monetary regime, the burden of macroeconomic management rests largely on fiscal policy. Fiscal reforms have improved revenue collection and spending efficiency (IMF (International Monetary Fund), 2018a), resulting in a series of small deficits and surpluses. Operationally, the government has been running a small surplus on the current balance, with foreign grants and concessional lending covering most capital expenditures (Chart 4). The cyclically-adjusted balance has improved significantly since the GFC (Chart 5). Before the Covid-19 pandemic, gross external debt had stabilized at about 30 percent of GDP, and by 2019 the government had deposits equal to about 15 percent of GDP at the NBC (Chart 6). ${ }^{11}$ Net public external debt declined from its peak of 39 percent of GDP in 2003 to 13 percent in 2019. As all borrowing was on concessional terms, public debt service in 2015-19 averaged only about 0.3 percent of GDP. Nevertheless, the authorities are anxious to better understand the transmission channels and simulate the impact of large macroeconomic shocks on fiscal sustainability. ${ }^{12}$ The biggest current shock is, of course, Covid-19.

\section{B. Calibration}

The answers any model gives depend crucially on its parameter values. We calibrate the CAMFI to capture country-specific features, as suggested by Berg, Karam, \& Laxton (2006). The adequacy of a model for policy analysis depends primarily on how well it captures the main transmission channels. For example, we expect the model to provide reasonable estimates of the sensitivity of net public debt to the business cycle or exchange rate passthrough.

To this end, our choice of parameters is based on four considerations: (1) Whenever it is meaningful, we econometrically assess the relationships or base the calibration on expert judgment. This approach is suitable, for example, to assess the persistence of such variables as the output gap. (2) Where the necessary data are available, we compare the model impulse response functions with empirical evidence; for Cambodia, however, empirical results are limited, see Rungcharoenkitkul (2012). (3) We assess whether the model can produce such unobserved variables as potential output or the equilibrium real exchange rate that would be consistent with the generally accepted narrative

withdrawal would crowd out private lending and the net government position would become less negative. As long as money supply remains unchanged, private sector credit would be a residual item and would have to decline one-for-one with the drawdown of government deposits.

10 The empirical literature on aid agrees that donors, other than multilateral donors, act procyclically on average. Donors typically do not increase concessional
10 10 The empirical literature on aid agrees that donors, other than multilateral donors, act procyclically on average. Donors typically do not increase concessional
disbursements during crises, but aid disbursements decline as recipient countries tend to fail conditionality targets during crises (Bulír \& Hamann, 2008; Pallage, Robe, \& Bérubé, 2006; Romero-Barrutieta, Bulír, \& Rodríguez-Delgado, 2015).

${ }^{11}$ Cambodia has a formal external debt ceiling of 40 percent of GDP and a domestic debt ceiling of 15 percent but has not borrowed domestically at all.

${ }^{12}$ Several such shocks were explored during past technical assistance visits. For example, in February 2020 the European Commission decided to partially withdraw Cambodia's preferential access to the $\mathrm{EU}$ market "due to the serious and systematic violations of human rights principles" https://ec.europa.eu/commission/ presscorner/detail/en/ip_20_229. On January 1, 2020, casinos in the seaside resort of Sihanoukville were asked to shut down casinos-shut-as-cambodia-bans-online-gambling-idUSKBN1YZOO3. 
about the Cambodia business cycle (IMF (International Monetary Fund), 2018b, 2019). (4) Finally, the model must be able to generate reasonable recursive forecasts, with inflation and output converging to their steady-state values over the medium term.

\section{Test Driving the CAMFI}

In this section, we validate our calibration against the generally accepted narrative based on three considerations: impulse response functions, estimation of unobserved variables, and recursive forecasts.
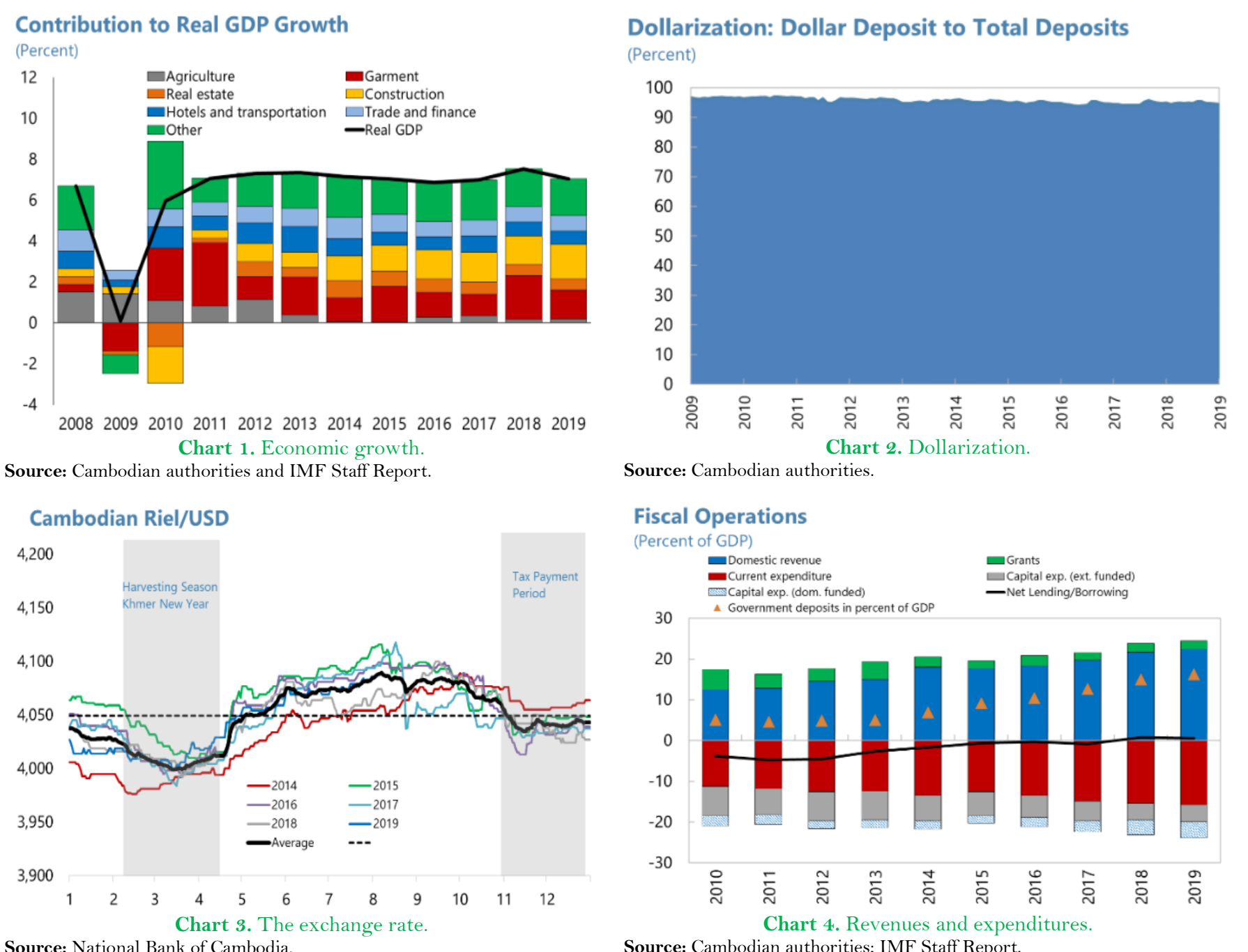

Source: National Bank of Cambodia.

Source: Cambodian authorities; IMF Staff Report.

\section{Cyclically-Adjusted Balance}

(Percent of GDP)

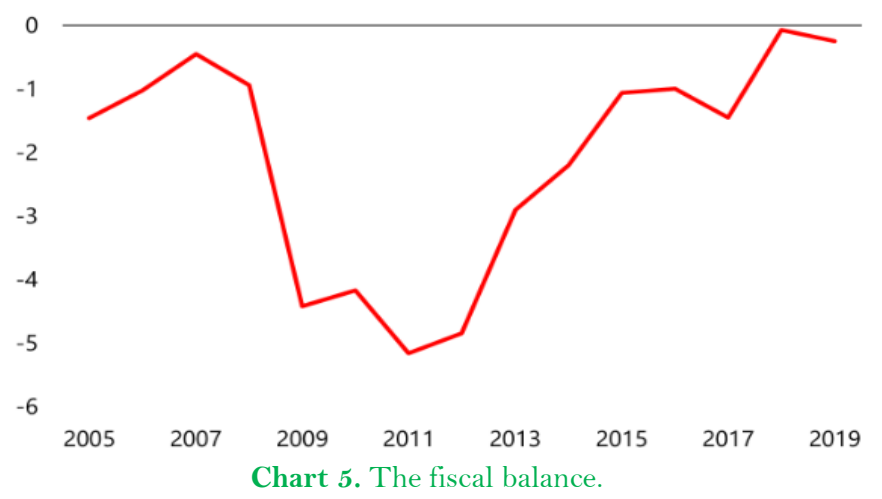

Debt, Grants, and Fiscal Deposits (Percent of GDP)

50

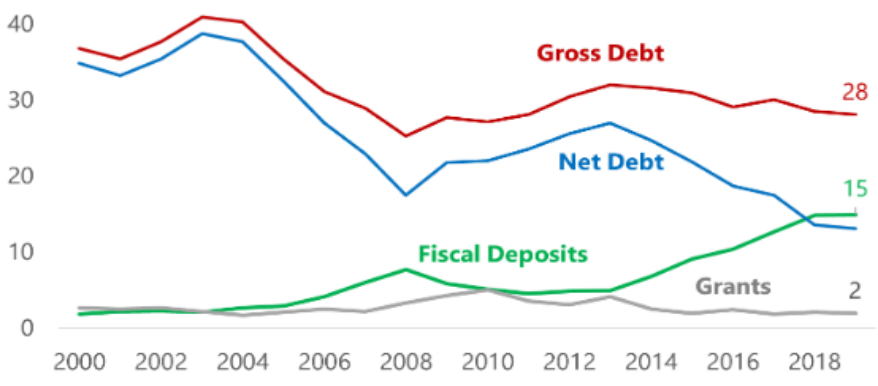

Chart 6. Net lending.

Source: Cambodian authorities; authors' calculations.

Figure 2. Cambodia: Selected stylized facts.

\subsection{Impulse Responses}

To assess the realism of the model's transmission mechanism, we explore its properties in terms of three impulse responses: (1) a shock to aggregate demand: an unexpected increase in the domestic output gap by 1 percentage point for one year; (2) a financial shock: an unexpected increase in the country risk premium by 1 percentage point for one year; and (3) unexpected temporary and permanent fiscal expansions: a shock to the primary deficit by 1 percentage point without and with a change in the debt target.

The impulse responses from a calibrated model must correspond to the available empirical evidence. Because empirical studies using Cambodian data are few, we rely on panel empirical studies (Fatás \& Mihov, 2001; Owyang, Ramey, \& Zubairy, 2013) for the shape of the impulse responses and on Batini, Eyraud, Forni, and Weber (2014) for the fiscal multipliers. Such studies provide stylized facts that our simulations attempt to mimic.

What are some of those stylized facts? (1) Because empirical effects of fiscal actions are long-lasting, stretching beyond seven years, the return to the steady state is necessarily much slower than in the monetary model outlined by Berg, Karam, \& Laxton (2006). (2) The impact of fiscal policy actions on output depends on the monetary regimewhen exchange rates are fixed, the multipliers tend to be higher than when exchange rates float. (3) The fiscal space 
matters: multipliers are higher in countries that can temporarily support higher debt-to-GDP ratios without sustainability concerns. (4) As long as one expects the debtor country to honor its debts, debt today will have to be serviced through consolidation in the future, which means the long-run multipliers will be around zero. ${ }^{13}$

\subsubsection{Aggregate Demand}

Figure 3 illustrates the implications of a positive aggregate demand shock in Cambodia. Windfall taxes and lower cyclical spending push the headline primary balance into surplus (recall that fiscal deficits are recorded as positive numbers), but the cyclically-adjusted primary balance first swings into a deficit because of the positive output gap. The debt-to-GDP ratio falls as the numerator expands; however, the fiscal authority will bring it back to the steady state through a series of expected future deficits. Neither the nominal exchange rate nor the nominal interest rate moves because the former is stabilized by central bank liquidity operations and the latter is linked to the world interest rate through the UIP. However, domestic inflation reacts to the output gap, causing the real exchange rate to appreciate relative to the steady state and creating a contractionary monetary stance. Though the output gap closes in about five years, gross debt and inflation take 10 years to return to the steady state.
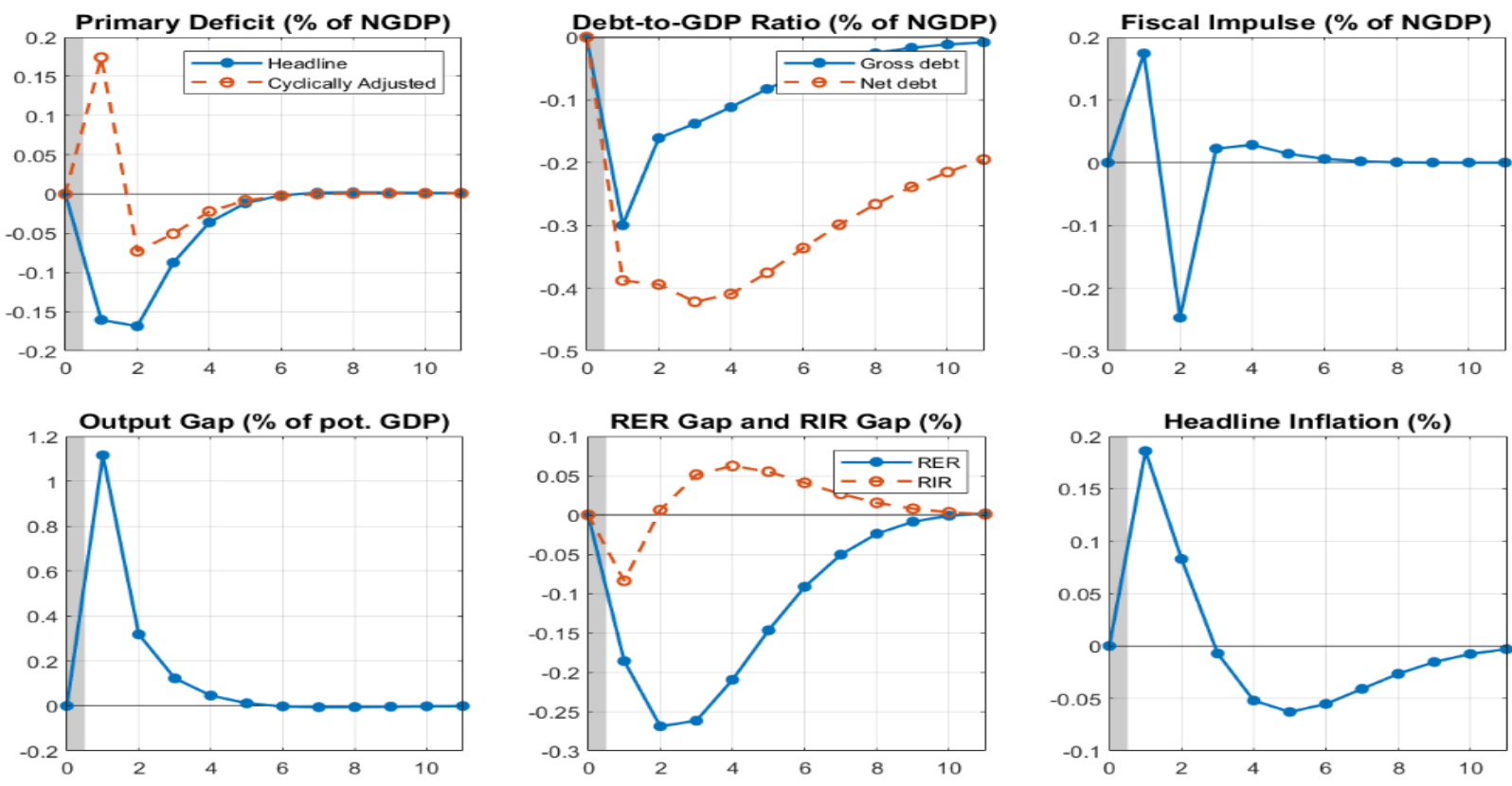

Figure 3. Dynamic responses of fiscal variables, GDP, real exchange rate, and inflation to a surprise one-year 1 percentage point increase in the output gap (Shock-minus-Control Responses).

Notes: The figure depicts dynamic responses to an increase in the domestic output gap at $\mathrm{t}=1$; the fiscal impulse is measured as the difference between the cyclically-adjusted primary deficit in $\mathrm{t}$ and $\mathrm{t}-1$; the RER (real exchange rate) gap is measured as the difference between the currentperiod value of the real exchange rate and its equilibrium value of the real exchange rate, and the RIR (real interest rate) gap is measured as the difference between the current-period value of the real interest rate and the rate's equilibrium value.

Source: CAMFI, authors' simulations.
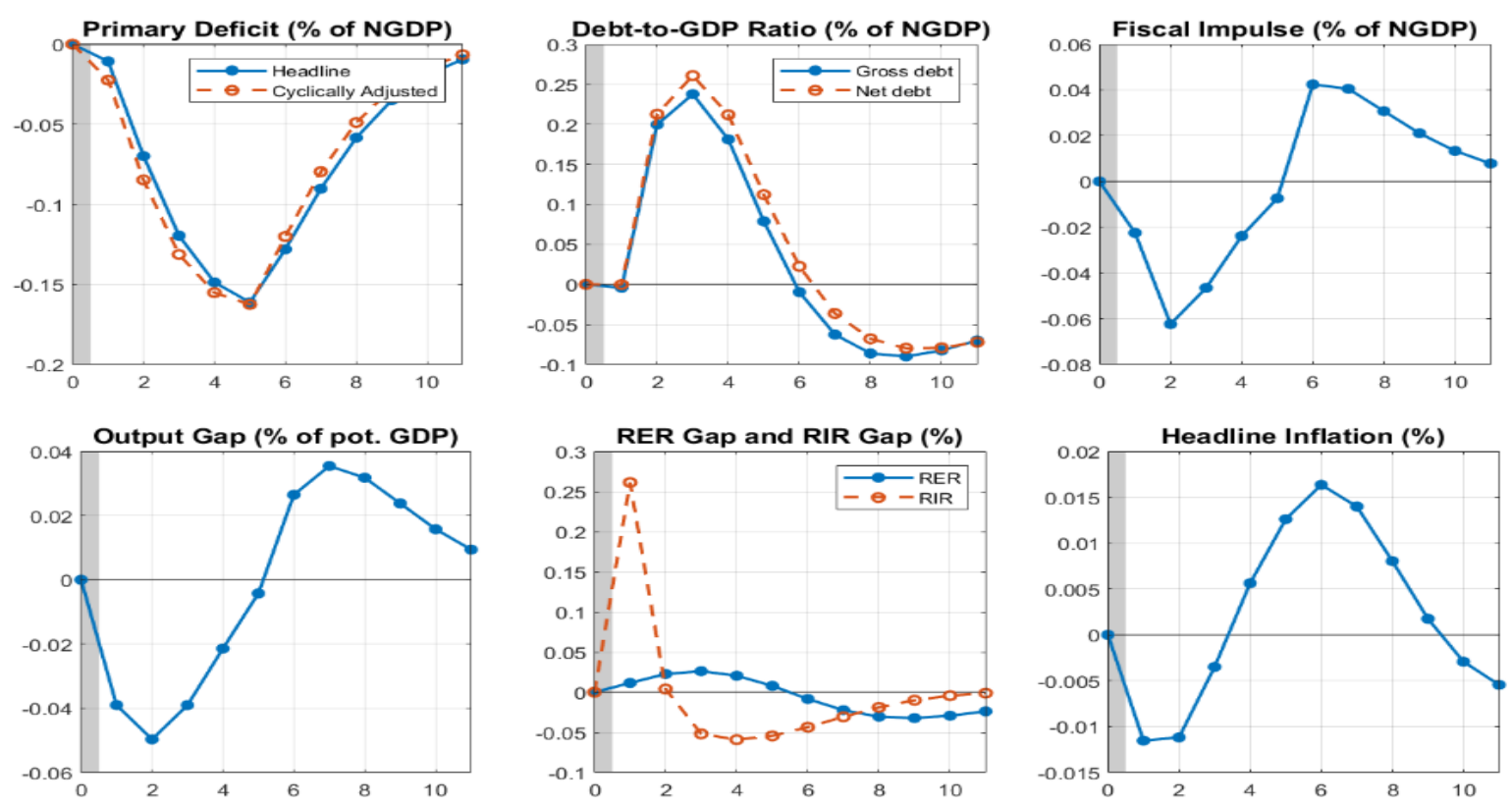

Figure 4. Dynamic responses of fiscal variables, GDP, real exchange rate, and inflation to an unexpected 1 percentage point rise in the country risk premium for one year (Shock-minus-Control Responses).

Notes: The figure depicts dynamic responses to an increase in the primary deficit at $t=1$; the fiscal impulse is measured as the difference between the cyclically-adjusted primary deficit in $\mathrm{t}$ and $\mathrm{t}-1$; the RER (real exchange rate) gap is measured as the difference between the current-period value of the real exchange rate and its equilibrium value, and the RIR (real interest rate) gap is measured as the difference between the current-period value of the real interest rate and the rate's equilibrium value. Source: CAMFI, authors' simulations.

\subsubsection{Risk Premium}

Figure 4 illustrates the implications of a short-lived monetary tightening abroad or a negative domestic confidence shock. The real domestic private-sector interest rate, $r_{t}$, accommodates the interest rate increase from

${ }^{13}$ Positive long-run fiscal multipliers can happen: a country may invest loan proceeds into physical or human capital that would yield positive returns long after the initial deficit-financed public spending or tax cut. 
abroad, tightening the monetary stance. The adverse output impact is relatively small compared to the increase in the debt-to-GDP ratio, so the fiscal authority tightens its stance, bringing the debt level back to the steady state. (Recall that the concessional rate applied to public debt is not affected by the risk premium moves.) It is worth noting that the return to the steady state takes more than 10 years, even though the initial risk-premium shock was for one year only.

\subsubsection{Fiscal Multiplier}

Figure 5 compares the implications of a one-period fiscal expansion-a widening of the primary deficit by 1 percent of GDP-in two hypothetical scenarios: (1) A temporary fiscal expansion implies that the fiscal authority will bring now-higher gross debt back to its target level, and in doing so it will be guided by the fiscal policy reaction function. (2) A permanent fiscal expansion implies that the fiscal authority will permanently revise the debt-to-GDP target for the stimulus upward by 1 percentage point. Although the impact multiplier is similar in both scenarios, whether the expansion is temporary or permanent has a profound impact on the long-run multiplier; while the longrun multiplier is zero for the permanent stimulus, it is negative for the temporary stimulus. With a temporary stimulus, the fiscal authority needs a longer series of primary surpluses to bring debt back to its target, thus withholding aggregate demand for longer.
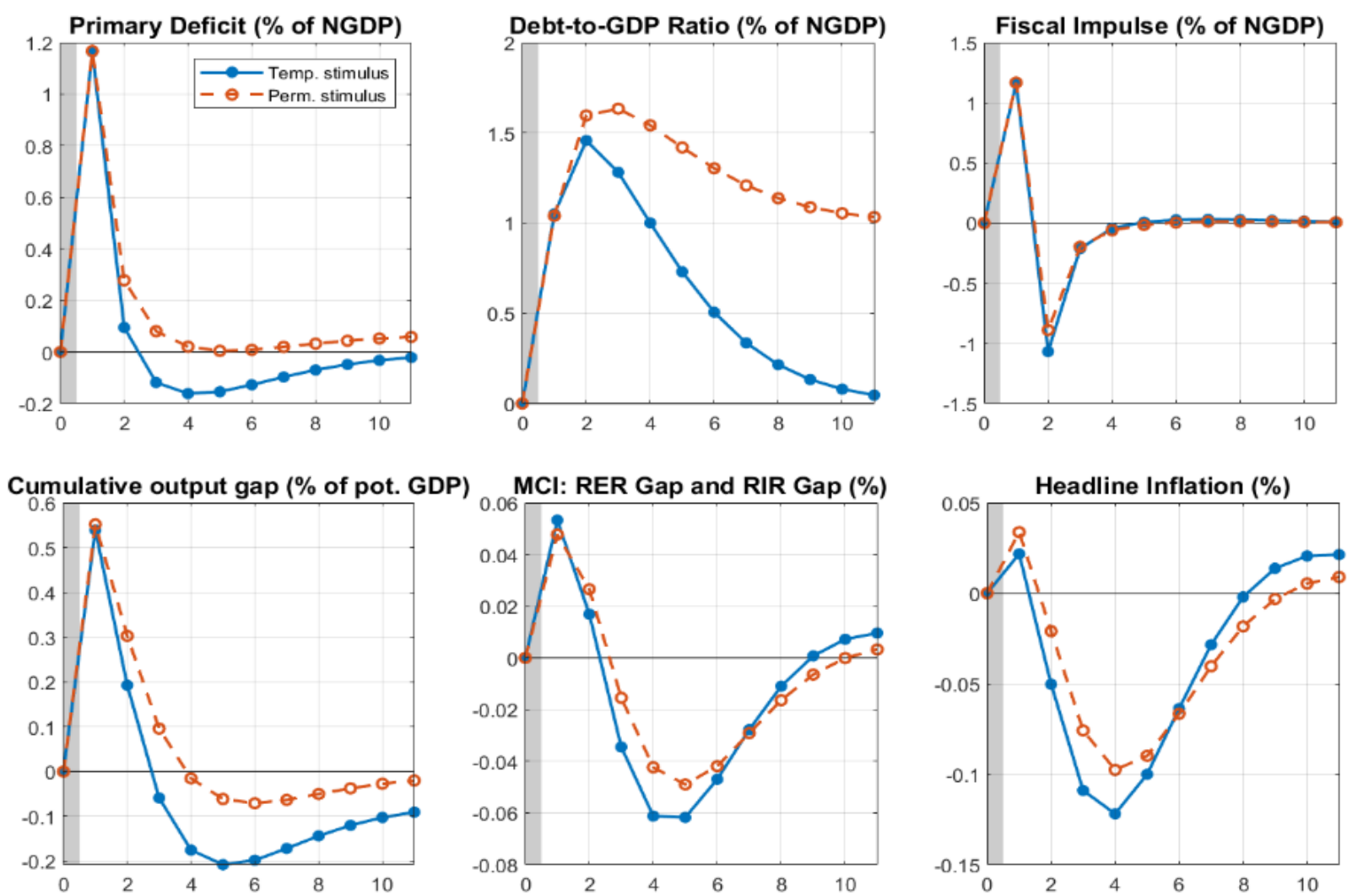

Figure 5. Dynamic responses of fiscal variables, GDP, real exchange rate, and inflation to an unexpected temporary 1 percentage point one-year stimulus and an unexpected one-year permanent fiscal stimulus (Shock-minus-Control Responses).

Notes: The figure depicts dynamic responses to an increase in the primary deficit at $t=1$; the fiscal impulse is measured as the difference between the cyclically-adjusted primary deficit in $t$ and $t-1$; the RER (real exchange rate) gap is measured as the difference between the current-period value of the real exchange rate and its equilibrium value, and the RIR (real interest rate) gap is measured as the difference between the current-period value of the real interest rate and the rate's equilibrium value. Source: CAMFI, authors' simulations.

\subsection{Multivariate Filter Results}

We believe that our multivariate-filter estimates for aggregate demand, aggregate supply, and fiscal variables are well-aligned with the typical narrative. We employ the model to estimate unobserved economic variables, the information in the observed variables, and the multivariate (Kalman) filter. The link between the observed and unobserved variables - the output, exchange rate, and interest rate gaps-is represented by the model itself. Conditional on the state form of the model and the observed variables, the multivariate filter can identify all unobserved variables and shocks. For linear systems, the Kalman filter represents an optimum estimate in terms of the least squares criterion (Hamilton, 1994). As some variables are nonstationary, without finite value variances, we employ the diffuse Kalman filter (De Jong, 1991).

The questions we ask are straightforward: Are the filter-derived unobserved variables consistent with the generally accepted narrative about the Cambodian business cycle (as in IMF (International Monetary Fund), (2018b); (2019))? Can we use the estimates of unobserved variables — the gaps - to explain such observed variables as inflation, output, and fiscal developments?

Our results suggest that Cambodia's economy was overheated before the GFC, driven by both the imported low interest rate and the undervalued exchange rate (Figure 6). The estimates further suggest that the authorities reacted with a fiscal impulse in 2009; however, the growth slowdown in 2012 was to a large degree attributable to a negative fiscal impulse that was only partly reversed in 2013. There seemed to be only very limited demand-side shocks postGFC.

Inflation peaked in 2008, driven by an overheated economy, an undervalued exchange rate, and the global foodprice shock (Figure 7). Inflationary shocks dissipated quickly, however, and inflation remained a few percentage points above the level of Cambodia's trading partners. As a result, the riel appreciated relative to its equilibrium 
value, though to a lesser degree than estimated in IMF (International Monetary Fund) (2019). As in our demandside estimates, inflation during the post-GFC period has been remarkably free of supply shocks.
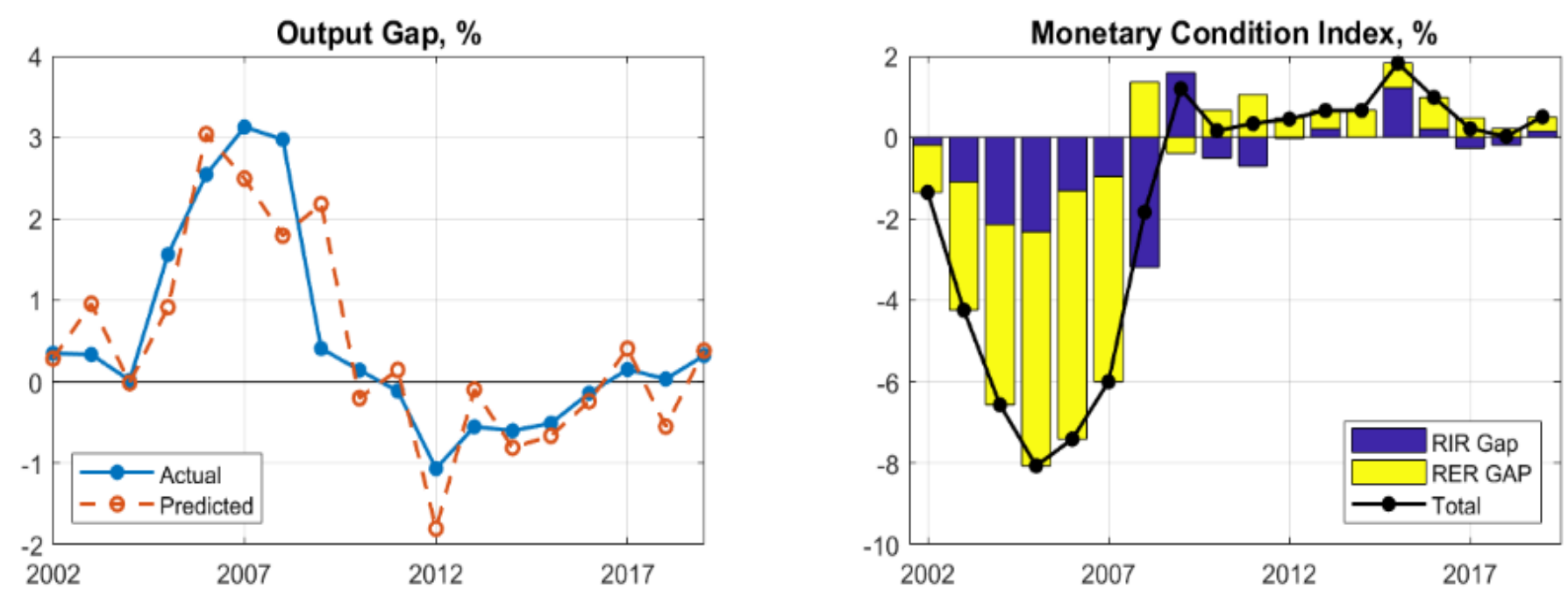

Output Gap Decomposition, \%

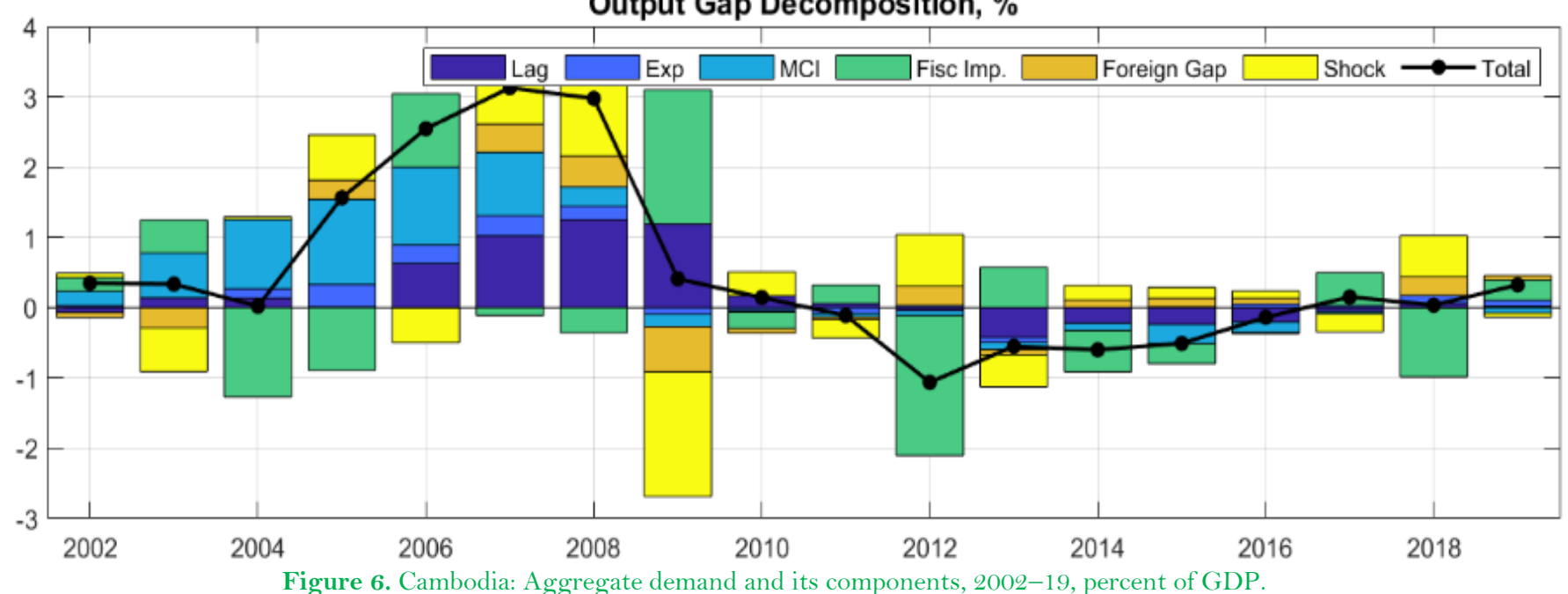

Note: A negative real exchange rate gap indicates an exchange rate that is overvalued relative to its trend value.

Source: CAMFI, authors' simulations.
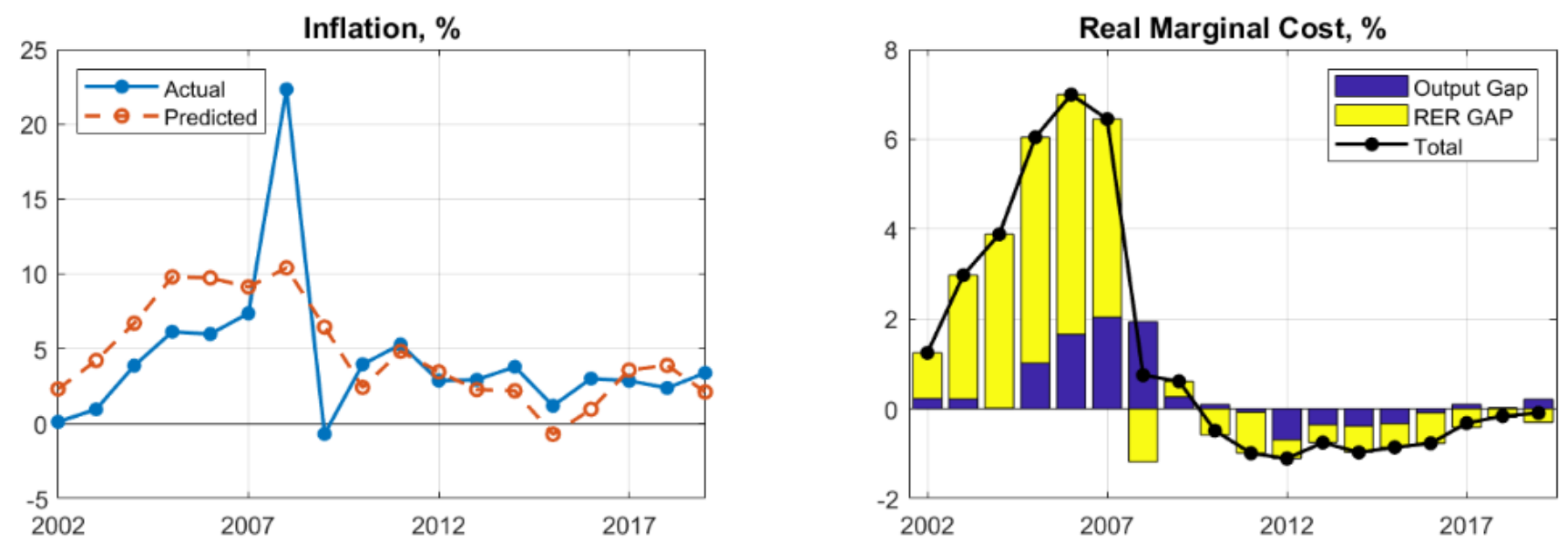

Inflation Decomposition, \%

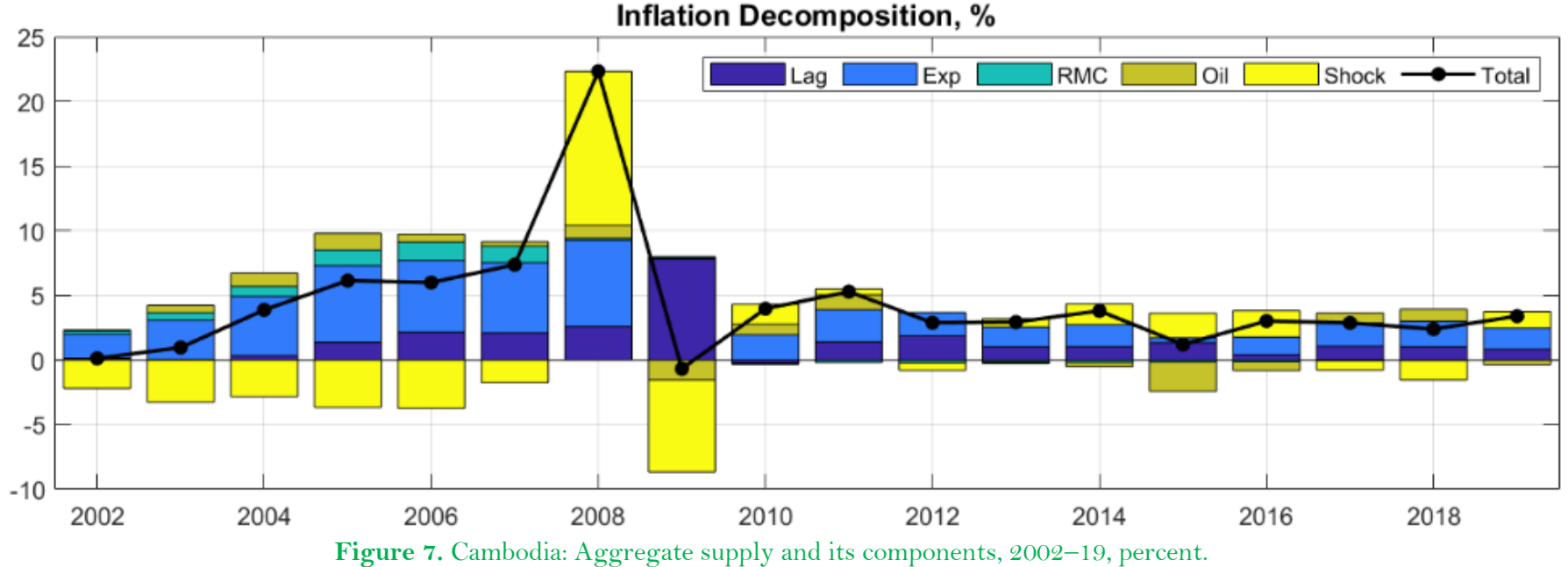

Source: CAMFI, authors' simulations. 
Post-GFC fiscal developments greatly benefitted from steady growth in real GDP. Cyclical smoothing-by about 2 percentage points of GDP-was apparent in 2010-12, as shown by the dark blue sections in the chart decomposing the fiscal balance (Figure 8). Thereafter the government ran a tighter fiscal stance than envisaged by the calibration of the fiscal policy reaction function (see the yellow sections in the bottom chart in 2012 and afterward). The stance allowed the government to accumulate sizable government deposits while keeping gross debt at the target level. In 2019 the actual deposit-to-GDP ratio was almost twice as high (15 percent) as our calibrated steady-state value of 8 percent; see Figure 2.
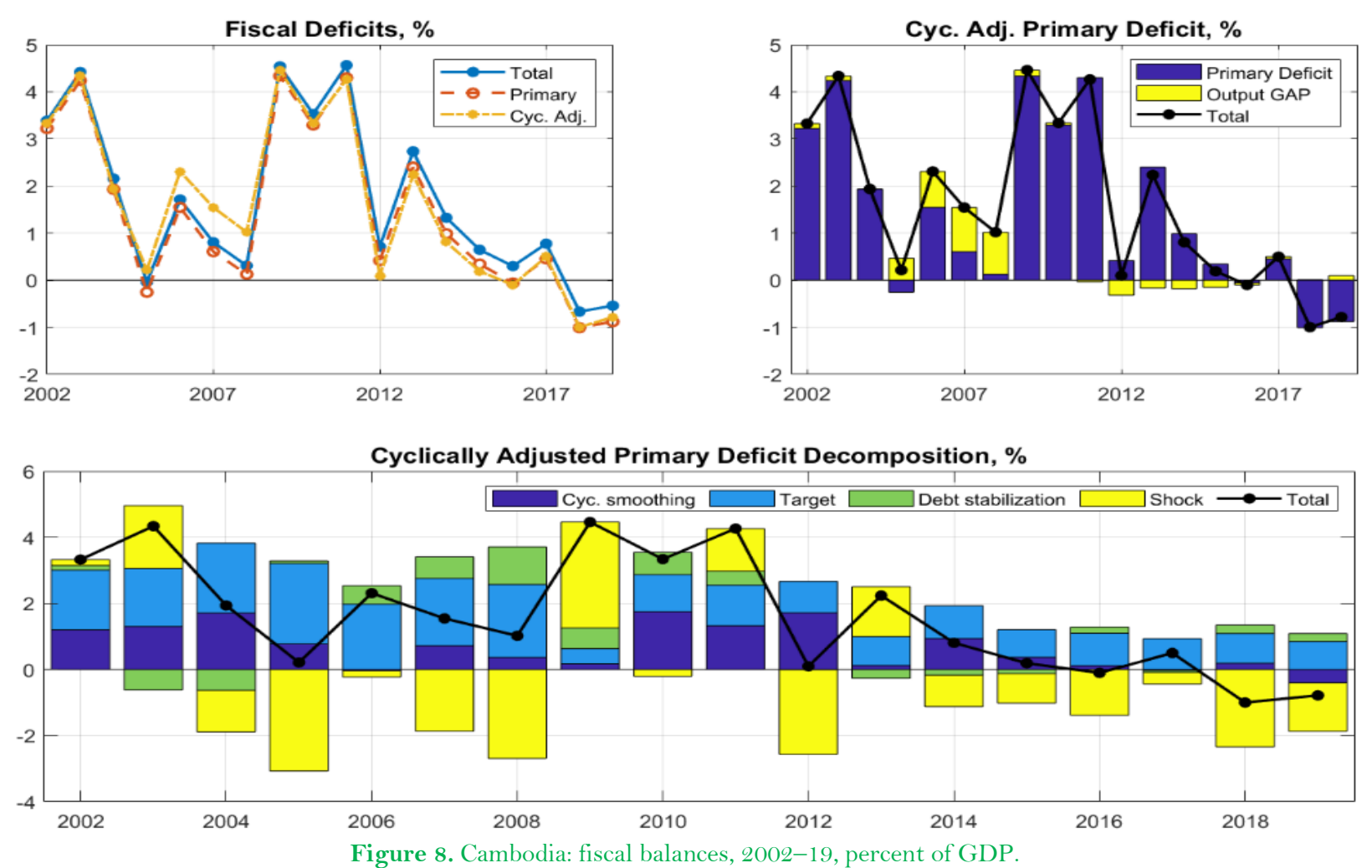

Note: A positive number indicates a deficit; a value of -1 for the primary balance in 2018 indicates a surplus of 1 percent of GDP.

Source: CAMFI, authors' simulations.

\subsection{Recursive Forecasts}

Next, we use the model-identified unobserved variables to assess the model's predictive ability. Mechanically, we employ the Kalman filter to identify the initial conditions for each year $(t)$ and make a series of 8-years-ahead recursive forecasts. All domestic variables are forecast endogenously, but we use their actual realizations for foreign variables. We then shift the model-identified initial conditions by one year and make another 8-years-ahead forecast, and so on. Figure 9 summarizes all 17 of our recursive forecasts - from 2003 to 2019 - forming a series of "spaghetti" charts for the variables of interest.

The model generates reasonable recursive forecasts: they predict most of the turning points in output and inflation. The missed turning points can be traced back to supply-side, external, and policy developments that are exogenous to our simple model, such as the post-conflict recovery of GDP in 2004-05, the global food price shock of 2007-08, and the post-GFC policy decision to accumulate fiscal deposits and drive down the net debt-to-GDP ratio. Our chosen form of the UIP captures the interest rate and exchange rate nexus very well. The fiscal variables, especially during the fast-growth pre-GFC and post-2012 periods, are in line with the goal of keeping gross debt at about 30 percent of GDP while bringing net debt lower during cyclical upswings.
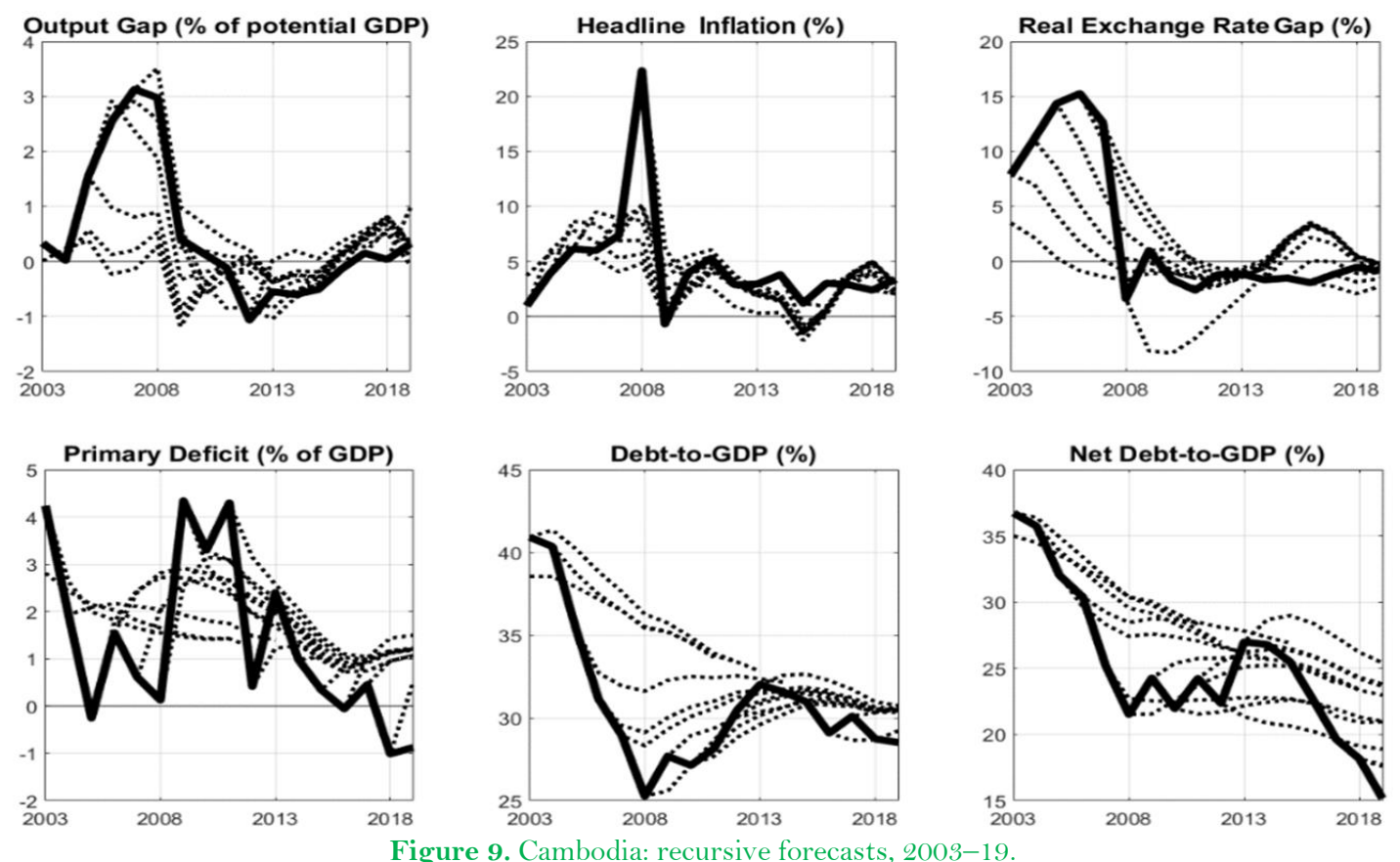

Figure 9. Cambodia: recursive forecasts, 2003-19. 


\section{A Policy-Relevant Exercise}

We now test the model on a counterfactual scenario of the economic impacts of the Covid-19 pandemic on Cambodia. We hasten to say that the scenario does not represent official macroeconomic projections of the IMF or Cambodian authorities and was designed primarily to showcase the scenario-making and reporting capabilities of the model: all judgmental assumptions are entirely our own. Indeed, the scenario paints a more pessimistic picture of the pandemic than the April 2020 World Economic Outlook(WEO) projection for Cambodia.

\section{A. Scenario Building and Assumptions}

The analysis depends on three layers of assumptions: (1) a recession in its trading partners affects demand for Cambodia's exports and leads to a collapse in tourist arrivals; (2) a second-round impact on domestic demand and supply that affects the country risk premium, working through the expectations channel; and (3) a fiscal response as the government introduces a fiscal stimulus to mitigate the impact of the previous two layers. The scenario is then compared with the baseline built around the pre-Covid-19 WEO growth projection.
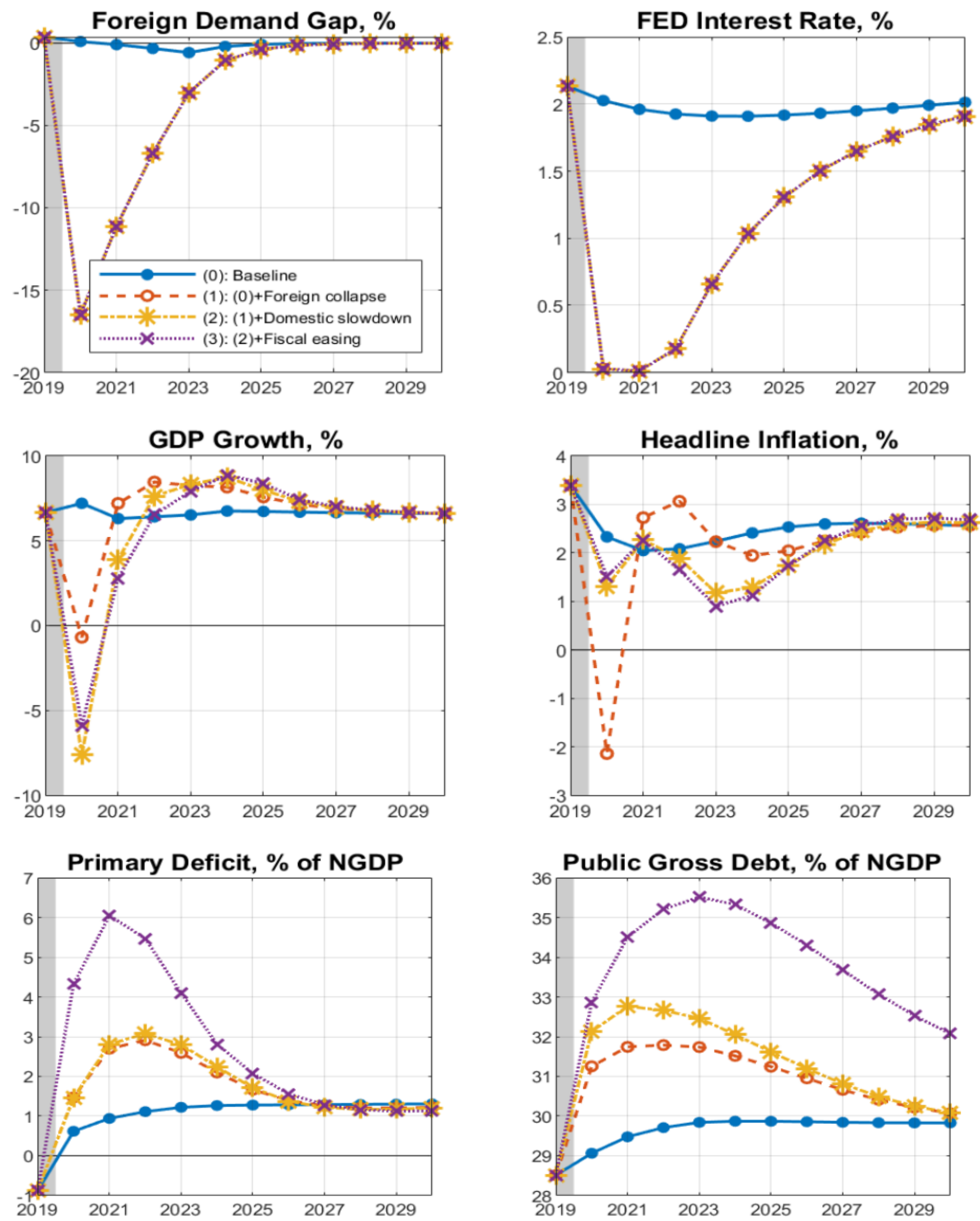

Notes: The blue line (0) denotes the simulation based on initial pre-pandemic conditions. The red (1), yellow (2), and purple (3) lines denote the layers of assumptions described in the text.

Source: CAMFI, authors' simulations. 
For the first layer, it is assumed that economic activity declines significantly in France, Germany, the US, and the UK (Figure 10). We also assume that the US Federal Reserve System keeps the policy rate at or near zero in 2020 and 2021 before gradually lifting it toward its neutral level of about 1 percent. Oil prices plunge in 2020 and are assumed to recover only slightly in 2021 . The second layer captures a decline in domestic demand, driven by the drop in private consumption and investment as domestic agents start to expect a global recession. Analyses of the Cambodia national account data, input-output tables, and the GFC experience suggest that domestic demand could drop by cumulative 2 percentage points in 2020-1, and the country risk premium could stay higher by 200 bps in 2020-1 due to tighter global financial conditions for emerging market economies. Food prices increase as pre-crisis food supply channels are interrupted. The initial Covid-19 shock is, of course, not anticipated by domestic agents.

In the second layer, we also make a judgment call about the medium-term supply-side disruptions caused by the pandemic. Tourism travel restrictions extending into 2021, or even 2022, and a sustained decline in demand for Cambodian export goods are likely to slow investment in both physical and human capital. The corresponding slowdown in productivity growth and disruptions in the supply chains would suppress potential GDP growth for some time. Compared to the steady state, we therefore envisage a scenario of cuts of 4.5 in potential GDP growth in 2020 and 3.5 percentage points in 2021 , which would only fully dissipate by 2024. ${ }^{14}$ The judgment call was guided by the estimated decline in the natural rate of interest in past pandemics (Jordà, Singh, \& Taylor, 2020) and the Penn Wharton model estimates of the lasting macroeconomic impacts of the coronavirus on the US (Dinerstein \& Huntley, 2020) and emerging market economies (S\&P Global Ratings, 2020).

The third layer of the Covid-19 scenario captures the impact of a possible discretionary fiscal response. Specifically, our scenario assumes that the public debt target temporarily goes up by 5 percentage points in 2020 and only gradually returns to the original level. In the model, the agents fully anticipate the fiscal response: the authorities and private agents share the same information.

\section{B. The Results}

The simulation results from the counterfactual scenario suggest a deep recession in 2020 before a gradual recovery starting in 2021. As shown in the third chart in Figure 10, in the first layer, the recession in advanced economies could bring Cambodia's growth down to $-1 \frac{1 / 4}{4}$ percent in 2020, compared to the baseline projection of 6 percent. In the second layer, domestic demand slows economic growth to $-8^{1 / 4}$ percent. Headline inflation is projected to decline slightly because of slackening in the economy and lower oil prices. These two factors offset the 4percentage point increase in domestic food prices due to supply channel interruptions and the resulting hoarding of food.

In the third layer of the scenario, we expect the fiscal stimulus to boost real growth by about $2 \frac{1}{2}$ percent, bringing GDP growth to $-5 \%$ percent. The economy will start to recover in 2021 , growing at almost 3 percent and closing the output gap in 2022. We note that the fiscal stimulus has only a short-lived impact on growth-the scenario assumes only a temporary increase in the debt target, similar to the GFC episode. Needless to say, the temporary nature of the debt target increase is announced, and it remains credible.

The results of the fiscal stimulus layer should be taken with a grain of salt. The model assumes a fiscal multiplier of $1 / 2$ based on cross-country experience (Appendix B). Should the actual fiscal multiplier be lower, the effect of the fiscal stimulus will be smaller; if the multiplier is higher, the effect will be larger. The case for a smaller fiscal multiplier could be based on the limited effectiveness of spending and lags in budget implementation. The case for a larger multiplier could be supported by the fact that additional public spending targets liquidity-constrained households and that during this crisis import leakages are likely smaller.

\section{Caveats and Potential Extensions}

We have designed and calibrated a simple, macro-fiscal, semi-structural model and applied it to Cambodia, CAMFI. Though this parsimonious model has obvious limitations, many of them can be addressed by extending the model with additional blocks. Because of the structure of Cambodia's economy and data availability problems, we have emphasized the simplicity of the model—realizing that simplicity comes at the cost of there being only a rudimentary supply side and ignoring many stock-and-flow relationships. For example, we capture fiscal accounting, but there is no treatment of the current account or the NBC balance sheet. Possible extensions suitable for more complex economies might be, among others, separation of core and noncore price indexes, breakdown of aggregate demand into an agricultural (commodity) component and a nonagricultural (non-commodity) component, development of the term structure of interest rates, and explicit modeling of external trade. Extensions of the model need to be weighed against data availability and the modeling complexity that extensions may introduce. It is highly important, however, that the model retain its conceptual simplicity and clarity; an overly complex model is unlikely to facilitate a fast and straightforward discussion of policy-relevant issues.

Some extensions are simple, such as accounting for alternative monetary and exchange rate regimes. There is a library of matching formulations for the monetary policy reaction equation and the equations modeling the exchange rate that correspond to the characteristics of these regimes. We can build on a variety of semi-structural monetary models developed in the context of IMF technical assistance; they cover the continuum of cases from free floats and open/closed capital accounts to pegs and closed capital accounts.

Users need to be mindful of the model's predictive ability since the short series available for Cambodia prevent most attempts at econometric evaluation. Economically reasonable estimates of important parameters tend to cover a wide range, and it is sometimes difficult to decide between competing representations of the economy. Combining the calibration approach with Bayesian estimation, perhaps employing system priors, may help, but it is unlikely to overcome the data deficiencies in most low-income and emerging market countries (Andrle \& Benes, 2013)..$^{15}$ Ultimately, model users must never take a single parameterization of a particular model too seriously. Models help

\footnotetext{
${ }^{14}$ The simulated slowdown in potential GDP growth by 4.5 percentage points in 2020 implies a rate of growth of potential GDP of only 2.0 percent, since steady-state growth is calibrated at 6.5 percent.

${ }^{15}$ System priors are priors about the model's features and behavior as a system, such as the maximum duration of the response of debt to a particular shock. System priors would help to parametrize the model when the policymaker has a clear view of the policy horizon, but the model developer has insufficient data to estimate the transmission mechanism.
} 
in discussing and assessing risks to the forecast, but they are no substitute for understanding the data and the economy.

Also deserving more attention, perhaps, is the vulnerability of low-income and emerging-market countries to global financial market shocks to, among other factors, their risk premiums and rollover risk. It would be useful to explore in a more structured way the role of the exchange rate and the interest rate in the aggregate demand, aggregate supply, and debt equations. We know relatively little about the effects of balance sheet mismatches or unsustainable debt on economies like that of Cambodia. These extensions will be difficult to apply in the current linear framework; the reaction of financial market and debt developments is known to be nonlinear.

\section{Conclusions}

This paper describes an approach to simulating and forecasting macroeconomic variables using CAMFI, a simple, macro-fiscal, semi-structural model. Unlike traditional IMF-detailed financial programming, the results here focus on only a few variables that are consistent with the New Keynesian framework that is the usual practice in modern academic literature, policymaking, and forecasting. Needless to say, the model's small size does not necessarily mean that operating such a semi-structural model is easy. Model developers and users need to start with a clear understanding of how the data are constructed, collect the key stylized facts, and pay attention to changes in the transmission mechanism as economies evolve.

We have outlined a basic version of the model and calibrated a parsimonious version of it for Cambodia, validating our calibration by using only a few impulse response functions, testing the consistency of unobserved variables against a generally accepted narrative, and assessing the accuracy of our recursive forecasts. We then used the model to simulate the medium-term economic impact of the Covid-19 pandemic. We demonstrated the relative ease and consistency with which a stacked set of assumptions can be developed into a full-blown counterfactual scenario and presented to the policymaker. We contend that this framework can be tailored to virtually any fiscal, monetary, or exchange rate policy regime. However, the startup costs to begin using even a relatively simple model of this type are substantial, and its sustained use requires periodic updates and maintenance.

\section{References}

Alesina, A., \& Ardagna, S. (2010). Large changes in fiscal policy: Taxes versus spending. Tax Policy and the Economy, 24(1), 35-68.Available at: https://doi.org/10.1086/649828.

Andrle, M., \& Benes, J. (2013). System priors: Formulating priors about DSGE models' properties. IMF Working Paper No. 13/257 (Washington: IMF).

Batini, N., Eyraud, L., Forni, L., \& Weber, A. (2014). Fiscal multipliers: Size, determinants, and use in macroeconomic projections. IMF Technical Notes and Manuals No. 2014/04 (Washington: IMF).

Berg, A., Karam, P.D., \& Laxton, D.L. (2006). A practical model-based approach to monetary policy analysis-overview. IMF Working Paper No. 06/80 (Washington: IMF)

Bulíř, A., \& Hamann, A. J. (2008). Volatility of development aid: From the frying pan into the fire? World Development, 36(10), 20482066.Available at: https://doi.org/10.1016/j.worlddev.2007.02.019.

Bulír, A., \& Vlček, J. (202 1). Monetary transmission: Are emerging market and low-income countries different? Journal of Policy Modeling, 43(1), 95-108.Available at: https://doi.org/10.1016/j.jpolmod.2020.06.006.

De Jong, P. (1991). The diffuse Kalman filter. The Annals of Statistics, 19(2), 1073-1083.

Dinerstein, M., \& Huntley, J. (2020). Lasting macroeconomic impacts of the coronavirus crisis, absent fiscal policy response. Penn Wharton budget model blog. Retrieved from https://budgetmodel.wharton.upenn.edu.

Engen, E., \& Hubbard, R. G. (2004). Federal government debt and interest rates. NBER Working Paper No. 10681 (Cambridge, MA: National Bureau of Economic Research).

Fatás, A., \& Mihov, I. (2001). The effects of fiscal policy on consumption and employment: Theory and evidence. CEPR Discussion Papers No. 2760. (London: Center for Economic and Policy Research).

Fedelino, A., Ivanova A., \& Horton, M. (2009). Computing cyclically adjusted balances and automatic stabilizers. Technical notes and manuals (Washington: IMF). Retrieved from http://www.imf.org/external/pubs/ft/tnm/2009/tnm0905.pdf.

Fukac, M., \& Pagan, A. (2010). Structural macro-econometric modelling in a policy environment. Research Working Paper, No. RWP 10-08 (Kansas City: Federal Reserve Bank of Kansas City).

Giavazzi, F., \& Pagano, M. (1996). Non-Keynesian effects of fiscal policy changes: International evidence and the Swedish experience. Swedish Economic Policy Review, 3(1), 67-112.

Hamilton, J. (1994). Time series analysis. Princeton: Princeton University Press.

HM Treasury. (2008). Fiscal Policy in the UK. London: HM Treasury.

Ilzetzki, E. (2011). Fiscal policy and debt dynamics in developing countries. Policy Research Working Paper Series No. 5666 (Washington: World Bank).

IMF (International Monetary Fund). (2018a). Cambodia: Technical assistance report—-tax administration modernization priorities $2019-23$. IMF Country Report No.18/305 (Washington: IMF). Retrieved from https://www.imf.org/en/Publications/CR/Issues/2018/11/07/Cambodia-Technical-Assistance-Report-Tax-AdministrationModernization-Priorities-201923-46336.

IMF (International Monetary Fund). (2018b). Cambodia: 2018 article IV consultation; Press Release; Staff Report (Washington: IMF). Retrieved from https://www.imf.org/ /media/Files/Publications/CR/2018/cr 18369.ashx.

IMF (International Monetary Fund). (2018c). Annual Report on Exchange Arrangements and Exchange Restrictions 2018. (Washington: IMF). Retrieved from https://www.elibrary-areaer.imf.org/Documents/YearlyReport/AREAER_2018.pdf.

IMF (International Monetary Fund). (2019). Cambodia: 2019 article IV consultation; Press release; Staff Report. (Washington: IMF). Retrieved from https://www.imf.org/ / media/Files/Publications/CR/2019/1KHMEA2019001.ashx.

Jaramillo, L., \& Weber, A. (2012). Bond yields in emerging economies: It matters what state you are in. IMF Working Paper No.12/198 (Washington: IMF).

Jordà, Ò., Singh, S.R. S., \& Taylor, A.M. (2020). Longer-run economic consequences of pandemics. NBER Working Paper No. 26934 (Cambridge, MA: National Bureau of Economic Research).

Kamenik, O., Tuma, Z., Vavra, D., \& Smidova Z. (2013). A simple fiscal stress testing model: Case studies of Austrian, Czech and German economies. OECD Economics Department Working Papers No. 1074 (Paris: OECD).

Obstfeld, M., Shambaugh, J. C., \& Taylor, A. M. (2005). The trilemma in history: Tradeoffs among exchange rates, monetary policies, and capital mobility. Review of Economics and Statistics, 87(3), 423-438.Available at: https://doi.org/10.1 162/0034653054638300.

Owyang, M. T., Ramey, V. A., \& Zubairy, S. (2013). Are government spending multipliers greater during periods of slack? Evidence from twentieth-century historical data. American Economic Review, 103(3), 129-134.Available at: https://doi.org/10.1257/aer.103.3.129.

Pallage, S., Robe, M. A., \& Bérubé, C. (2006). The potential of foreign aid as insurance. IMF Staff papers, 53(3), 453-475.

Plödt, M., \& Reicher, C. A. (2015). Estimating fiscal policy reaction functions: The role of model specification. Journal of Macroeconomics, 46, 113-128.Available at: https://doi.org/10.1016/j.jmacro.2015.08.005.

Price, R., Dang, T.-T., \& Botev J. (2015). Adjusting fiscal balances for the business cycle: New tax and expenditure elasticity estimates for OECD countries. OECD Working Paper No. ECO/WKP 1275 (Paris: OECD). 
Ramey, V. A., \& Zubairy, S. (2018). Government spending multipliers in good times and in bad: Evidence from US historical data. Journal of Political Economy, 126(2), 850-901.Available at: https://doi.org/10.1086/696277.

Romero-Barrutieta, A.L., Bulíř, A., \& Rodríguez-Delgado, J.D. (2015). The dynamic implications of debt relief for low-income countries. Review of Development Finance, 5(1), 1-12.

Rungcharoenkitkul, P. (2012). Modeling with limited data: Estimating potential growth in Cambodia. IMF Working Paper No. 12/96 (Washington: IMF).

S\&P Global Ratings. (2020). Economic research: COVID-19 deals a larger, longer hit to global GDP. Retrieved from https://www.spglobal.com/ratings/en/research/articles/200416-economic-research-covid-19-deals-a-larger-longer-hit-to-globalgdp-11440500.

Schumacher, M., \& Żochowski, D. (2017). The risk premium channel and long-term growth. ECB Working Paper No. 2114 (Frankfurt: European Central Bank).

World Economic Forum. (2019). Global competitiveness report. Retrieved from http://www3.weforum.org/docs/WEF_TheGlobalCompetitivenessReport2019.pdf.

\section{Appendixes}

\section{A. Fiscal Deposits}

Without ready access to international bond markets or opting to issue local bonds, the Cambodian government has been building deposits at the National Bank of Cambodia (NBC) as a buffer (see Figure 1, Chart 6 in the main text). The following identity holds:

\section{Change in fiscal deposits $=$ Overall deficit - Change in gross public debt}

How to model the fiscal deposits? On the one hand, the headline fiscal deficit has been correlated with the business cycle, that is, the output gap. On the other hand, the evolution of gross debt has reflected the 30-percent debt-toGDP target and fluctuations around that level caused by donor disbursement choices, progress in project execution, and so on. These stylized facts suggest that cyclical factors drive the gradual accumulation of fiscal deposits, as shown in Figure A1. In the model, we therefore calibrate the elasticity of the deposits to the output gap as equal to 0.3.

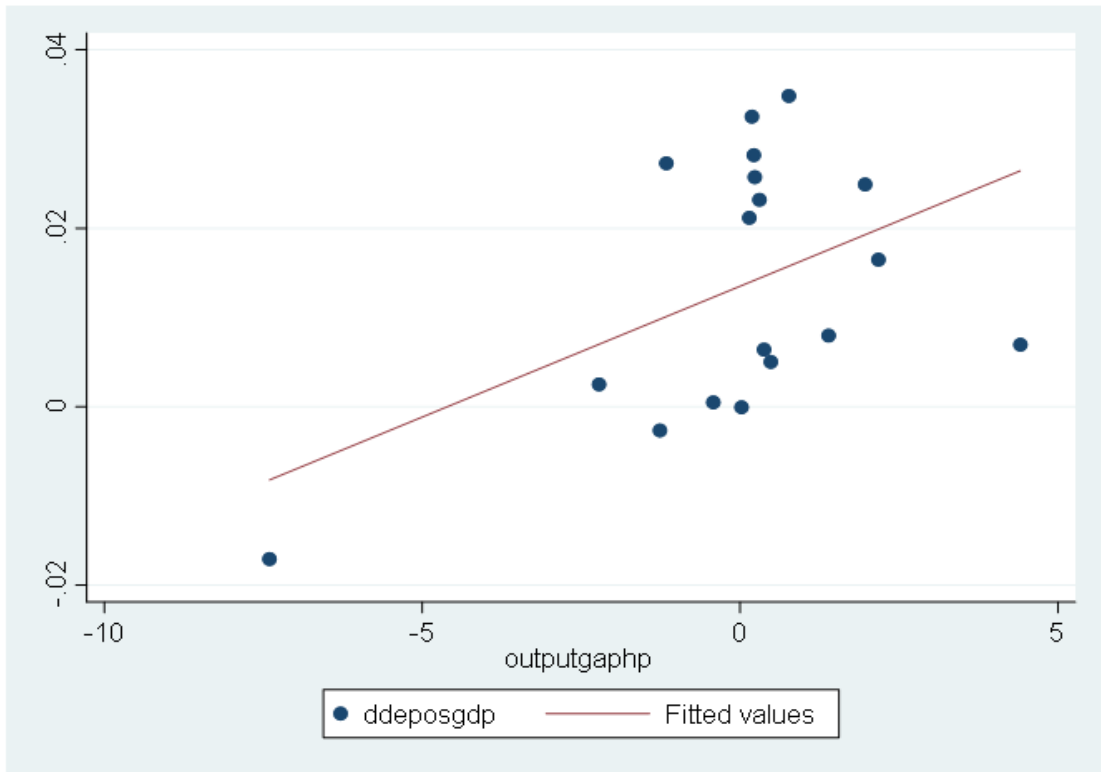

Figure A1. Output gap and fiscal deposits, 2002-19.

Notes: The figure shows fiscal deposits in percent of GDP on the vertical axis and output gap in percent of trend GDP on the horizontal axis. The fitted values line is the linear trend. Source: International Monetary Fund (IMF) data and authors' calculations.

\section{B. The Fiscal Multiplier Estimates for Cambodia}

The fiscal multiplier measures the impact on output of an unexpected, discretionary change in fiscal policy. Empirically, individual-country estimation of fiscal multipliers is fraught with problems (Owyang et al., 2013; Ramey \& Zubairy, 2018) even in countries with long, good-quality time series, and it is almost impossible in a country like Cambodia. Batini et al. (2014) have instead suggested a "bucket approach" to calibrate the magnitude of the multiplier based on country characteristics.

The empirical literature provides widely varying multiplier estimates for three reasons. (1) Because it is difficult to identify an unexpected, discretionary change in the fiscal variables, most developments in taxes and spending are instead reactions to the business cycle. (2) The fiscal multipliers, which vary over time and across countries and monetary policy regimes, draw on a range of factors, including the state of the economy, the specific fiscal instrument used, the extent to which fiscal decisions provoke changes in other policies, such as monetary, and the structure of the economy. (3) Because most empirical studies deal with advanced economies, relatively little is known about the size of the multiplier in emerging and low-income countries. One generally accepted finding is that spending multipliers in low-income countries are, on average, lower than in advanced economies (Ilzetzki, 2011). Table B1 summarizes some of the offsetting factors.

Table B1. Factors affecting the fiscal multiplier in low-income countries.

\begin{tabular}{l|l}
\hline Multiplier-increasing factors & Multiplier-decreasing factors \\
\hline - Less developed financial markets & - More open economy (import leakage) \\
- Less forward-looking economic agents & - Larger precautionary saving \\
- Less effective monetary policy response & - Inefficiencies in public spending and revenue administration \\
- Smaller automatic stabilizers & - Long-lasting positive output gaps due to supply constraints \\
- Lower government debt & \\
\hline
\end{tabular}


We apply the methodology of Batini et al. (2014) to calibrate Cambodia's fiscal multiplier in three steps, as shown in Table B2:

Step 1: Assign a score to Cambodia based on the number of characteristics associated with large fiscal multipliers: 1 if yes, $O$ otherwise.

Step 2: Sum up the scores to determine the likely bucket of the multiplier (low, medium, or high).

Step 3: Adjust the range assigned using the scoring method based on Cambodia's temporary characteristics.

After steps 1 and 2, Cambodia falls into the low-multiplier bucket, suggesting that the fiscal multiplier ranges between 0.1 and 0.3 . Adjusting for the temporary factors prevailing in 2020, the estimate of the first-year fiscal multiplier falls in the range of 0.5 to 0.7 . Hence, in the model, we calibrate the impact multiplier to be equal to 0.5.

Table B2. Cambodia's fiscal multiplier in 2020: the bucket approach.

\begin{tabular}{|c|c|c|c|}
\hline \multicolumn{4}{|l|}{ Step 1: Scoring the Characteristics } \\
\hline Characteristics & Assess & Score & Indicators [benchmark] \\
\hline Low trade openness & No & $\mathrm{O}$ & $\begin{array}{l}\text { Imports } / \text { GDP }=73 \% \text { (average past } 5 \text { years), }[> \\
40 \%]\end{array}$ \\
\hline High labor market rigidity & No & $\mathrm{O}$ & $\begin{array}{l}\text { Weak labor unions (World Economic Forum, } \\
\text { 2019) }\end{array}$ \\
\hline Small automatic stabilizers & Yes & 1 & Public spending/GDP $=23 \%,[<45 \%]$ \\
\hline Fixed exchange rate regime & Yes & 1 & Stabilized around 4,050 riels per US dollar \\
\hline Low public debt & Yes & 1 & Debt-to-GDP $=28 \%,[<40 \%]$ \\
\hline $\begin{array}{l}\text { Effective public expenditure and } \\
\text { revenue management }\end{array}$ & No & $\mathrm{O}$ & $\begin{array}{l}\text { Based on the } 2015 \text { evaluation of Public } \\
\text { Financial Management of Cambodia. }\end{array}$ \\
\hline \multicolumn{4}{|l|}{ Step 2: Total Score and Group } \\
\hline \multirow[t]{2}{*}{ Total score } & Low multiplier & 3 & Low multiplier, if the total score is less than 3. \\
\hline & Fiscal multiplier & $0.1-0.3$ & Low multiplier: between 0.1 and 0.3 \\
\hline \multicolumn{4}{|c|}{ Step 3: Adjustment for Temporary Factors } \\
\hline Composition of the fiscal stimulus & & 0.25 & $\begin{array}{l}\text { The fiscal stimulus involves both spending and } \\
\text { net taxes (increase the lower bound by } 0.5 \text { and } \\
\text { then divide by } 2 \text { ) }\end{array}$ \\
\hline Economic cycle & & 0.17 & $\begin{array}{l}\text { Negative output gap due to the Covid-19 } \\
\text { pandemic (adjustment, } 0.5^{*} 1 / 3 \text { ) }\end{array}$ \\
\hline Monetary policy & & 0.05 & Constrained by high dollarization $\left(0.1^{*} 1 / 2\right)$ \\
\hline The multiplier after adjustment & & $0.5-0.7$ & $\begin{array}{l}\text { The upper and lower ranges are adjusted by the } \\
\text { following additive factors: }+0.25 \text { (two-thirds of } \\
\text { the adjustment relates to expenditures), }+0.17 \\
\text { (large negative output gap), and }+0.05 \\
\text { (constrained monetary policy). }\end{array}$ \\
\hline
\end{tabular}

\section{The CAMFI Model Codes}

All Matlab model codes, including parameter values, and the corresponding version of the IRIS toolbox are available at: https://imfbox.box.com/s/9txhtrg77m37f4asf6tvo9cnuq4j9hh9.

The key model equations are as follows:

Aggregate demand (Dynamic IS curve):

The monetary conditions index:

$$
\hat{y}_{t}=a_{1} \hat{y}_{t-1}+a_{2} E_{t} \hat{y}_{t+1}-a_{3} m c i_{t}+a_{4} f_{t}^{i m p}+a_{5} \hat{y}_{t}^{*}+\varepsilon_{t}^{y},
$$

Aggregate supply (the New-Keynesian Phillips curve):

$$
m c i_{t}=a_{6}\left(\hat{r}_{t}+c r \_ \text {prem }_{t}\right)+\left(1-a_{6}\right)\left(-\hat{z}_{t}\right),
$$

Real marginal cost:

$$
\pi_{t}=b_{1} \pi_{t-1}+\left(1-b_{1}\right) E_{t} \pi_{t+1}+b_{2} r m c_{t}+b_{3} \Delta o i l_{t}+\varepsilon_{t}^{\pi}
$$

The uncovered interest rate parity (UIP) condition:

$$
r m c_{t}=b_{4} \hat{y}_{t}+\left(1-b_{4}\right) \hat{z}_{t}
$$

$$
i_{t}=\left(E_{t} s_{t+1}-s_{t}\right)+i_{t}^{*}+\text { prem }_{t}
$$

The nominal exchange rate:

$$
\Delta s_{t}=c_{1} \Delta s_{t-1}+\left(1-c_{1}\right)\left(\Delta \tilde{s}_{t}-c_{2} s_{t-1}\right)+\varepsilon_{t}^{S}
$$

The fiscal impulse:

$$
f_{t}^{i m p}=\left(\operatorname{cad}_{t}-\operatorname{cad}_{t-1}\right)+f_{4} \varepsilon_{t}^{b^{t a r}} \pm f_{5} \varepsilon_{t}^{b}
$$

The fiscal reaction function:

The cyclically-adjusted primary deficit:

$$
\operatorname{cad}_{t}=f_{7}\left(\operatorname{cad}_{t-1}-f_{10} \hat{y}_{t}\right)+\left(1-f_{7}\right)\left(\operatorname{cad}_{t}^{t a r}-f_{8} b_{t}^{d e v}\right)+\varepsilon_{t}^{c d}
$$

$$
\operatorname{cad}_{t}=p d_{t}+f_{3} \hat{y}_{t}
$$

The total deficit:

$$
d_{t}=p d_{t}+i d_{t}
$$

Expected debt deviation path:

$$
b_{t}^{\text {dev }}=f_{9}\left(b_{t}-b_{t}^{\text {tar }}\right)+\left(1-f_{9}\right) E_{t} b_{t+1}^{d e v}
$$


Gross debt accumulation:

Fiscal deposit accumulation:

$$
\begin{gathered}
b_{t}=d_{t}+\Delta x_{t}+\left(1+\Delta s_{t}\right) b_{t-1} /\left(1+g_{t}\right) \\
x_{t}=\Delta x_{t}+\left(1+\Delta s_{t}\right) x_{t-1} /\left(1+g_{t}\right)
\end{gathered}
$$

The fiscal deposit reaction function:

$$
\Delta x_{t}=g_{2} \Delta x_{t-1}+\left(1-g_{2}\right)\left(\Delta \tilde{x}_{t}+g_{3} \hat{y}_{t}+g_{4}\left(p d_{t}-p d_{t}^{\text {tar }}\right)\right)+\varepsilon_{t}^{x}
$$

Debt service:

$$
i d_{t}=i_{t-1}^{G o v}\left(1+\Delta s_{t}\right) b_{t-1} /\left(1+g_{t}\right)
$$

Purchasing power parity (PPP) condition:

$$
z_{t}=s_{t}+p_{t}^{*}-p_{t}
$$

The real interest rate trend:

$$
\tilde{r}_{t}=h_{5} \tilde{r}_{t-1}+\left(1-h_{5}\right)\left(\Delta \tilde{z}_{t+1}+\tilde{r}_{t}^{*}+\text { prem }_{t}\right)
$$

The country risk premium:

$$
\text { prem }_{t}=h_{6} \text { prem }_{t-1}+\left(1-h_{6}\right)\left(\text { prem }+h_{12}\left(b_{t}-\bar{b}-\left(x_{t}-\bar{x}\right)\right)\right)+\varepsilon_{t}^{\text {prem }}
$$

The equilibrium real exchange rate trend:

$$
\Delta \tilde{z}_{t}=h_{7} \Delta \tilde{z}_{t-1}+\left(1-h_{7}\right) \Delta \bar{z}+\varepsilon_{t}^{\Delta z}
$$

Potential output growth:

$$
\Delta \tilde{y}_{t}=h_{8} \Delta \tilde{y}_{t-1}+\left(1-h_{8}\right)\left(\Delta \bar{y}-h_{13}\left(\tilde{r}_{t}-\bar{r}\right)\right)+\varepsilon_{t}^{\Delta y}
$$

